\title{
Review Article \\ Differential Expression Patterns of Eph Receptors and Ephrin Ligands in Human Cancers
}

\author{
Chung-Ting Jimmy Kou and Raj P. Kandpal \\ Department of Basic Medical Sciences, Western University of Health Sciences, Pomona, CA 91766, USA \\ Correspondence should be addressed to Raj P. Kandpal; rkandpal@westernu.edu
}

Received 29 September 2017; Revised 11 January 2018; Accepted 22 January 2018; Published 28 February 2018

Academic Editor: Pasquale De Bonis

Copyright (c) 2018 Chung-Ting Jimmy Kou and Raj P. Kandpal. This is an open access article distributed under the Creative Commons Attribution License, which permits unrestricted use, distribution, and reproduction in any medium, provided the original work is properly cited.

\begin{abstract}
Eph receptors constitute the largest family of receptor tyrosine kinases, which are activated by ephrin ligands that either are anchored to the membrane or contain a transmembrane domain. These molecules play important roles in the development of multicellular organisms, and the physiological functions of these receptor-ligand pairs have been extensively documented in axon guidance, neuronal development, vascular patterning, and inflammation during tissue injury. The recognition that aberrant regulation and expression of these molecules lead to alterations in proliferative, migratory, and invasive potential of a variety of human cancers has made them potential targets for cancer therapeutics. We present here the involvement of Eph receptors and ephrin ligands in lung carcinoma, breast carcinoma, prostate carcinoma, colorectal carcinoma, glioblastoma, and medulloblastoma. The aberrations in their abundances are described in the context of multiple signaling pathways, and differential expression is suggested as the mechanism underlying tumorigenesis.
\end{abstract}

\section{Introduction}

The discovery of oncogenes and tumor suppressors in 1970s and subsequent advances in 1980s illuminated the mechanisms responsible for regulating the growth and proliferation of normal cells. The activation of protooncogenes and inactivation of tumor suppressors are frequently observed in cancer cells. In most cases, tumor cells display alterations in morphology, cell-cell interactions, membrane properties, cytoskeletal structure, protein secretion, and gene expression. Furthermore, transformed cells also exhibit loss of contact inhibition, self-sufficiency of growth signals, and escape from replicative senescence [1-4].

The growth and consequent metastasis of tumor cells are largely dependent on neovascularization [5], which is regulated by many different cellular signals including axon guidance molecules. Axon guiding signal molecules consist of Eph/ephrin, Semaphorins/plexins, VEGF/VEGFR, chemokines/chemokine receptors, netrins/DCC, Slit/Robo, and Notch/Delta [6]. In fact, altered abundance and regulation of these proteins have been associated with a variety of human cancers. We have focused here on Eph/ephrin molecules and their roles in tumorigenesis.

\section{Structure of Eph Receptors and Ephrin Ligands}

Eph receptors are important for development and tissue organization in multicellular organisms. These transmembrane (TM) proteins are activated by binding to ephrin ligands. Fourteen Eph receptors encoded in the human genome are divided into $\mathrm{A}$ and $\mathrm{B}$ classes. EphA receptors consist of nine members (EphA1-EphA8 and EphA10), which are activated by five different ephrin-A ligands. Five EphB receptors (EphB1-EphB4 and EphB6) bind to three ephrin$B$ ligands [7]. Although interactions of Eph receptors with their cognate class of ephrin ligands are well documented, interclass binding between Eph receptors and ephrin ligands has also been reported.

The native structure of Eph receptors displays an ephrinbinding domain, a cysteine-rich region, two fibronectin type III repeats, a transmembrane segment with conserved 


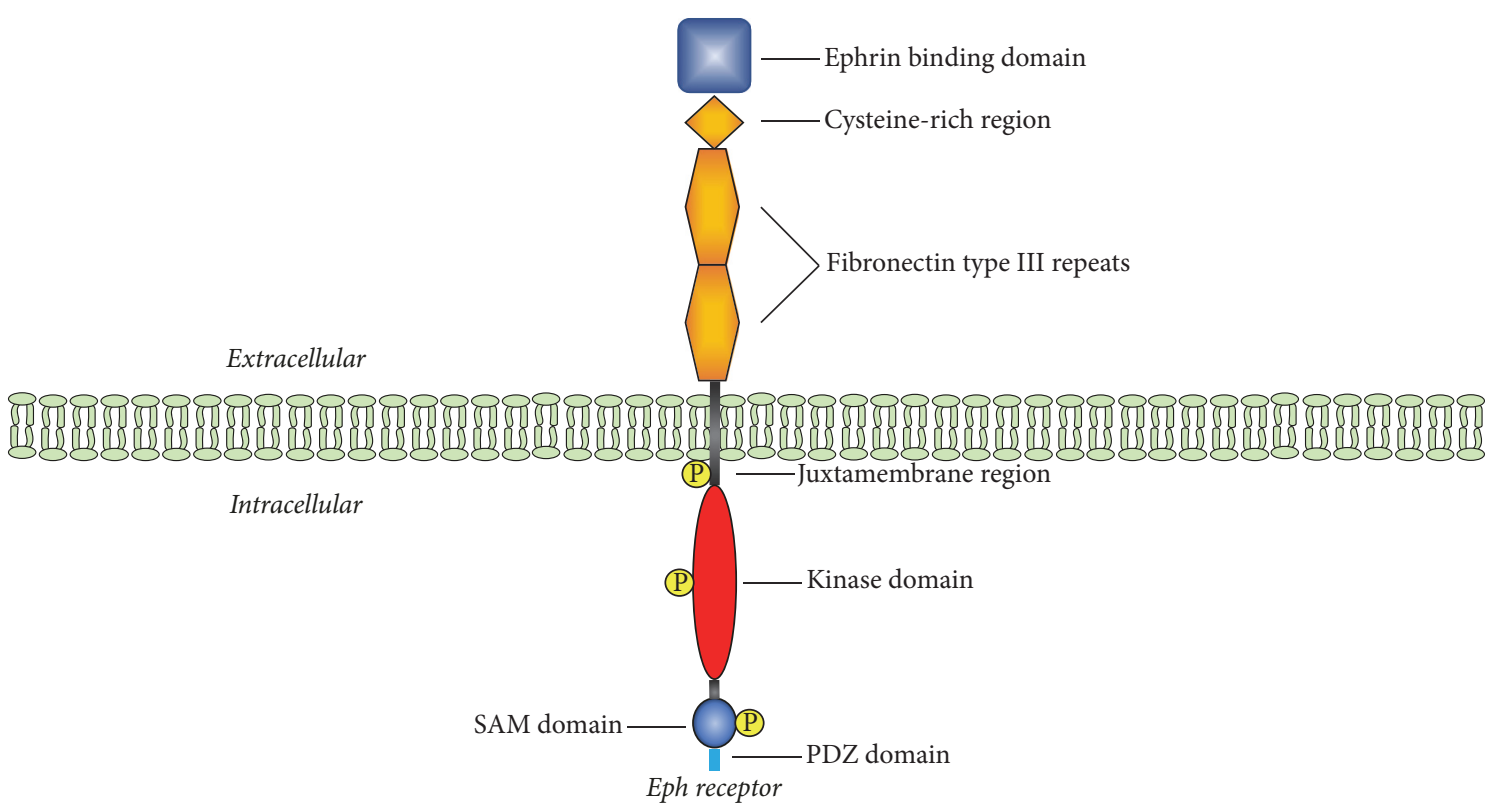

Figure 1: Domains in Eph Receptors. The cytoplasmic and extracellular portions of the receptor are separated by the membrane bilayer. The extracellular region of Eph receptors contains a ligand binding domain, a cysteine-rich domain, and two fibronectin type III repeats. The intracellular region is composed of a tyrosine domain, a sterile $\alpha$ motif (SAM), and a PDZ domain. The domains have been drawn in different shapes and colors, and individual domains are labeled with their designations. Phosphorylated residues are indicated.

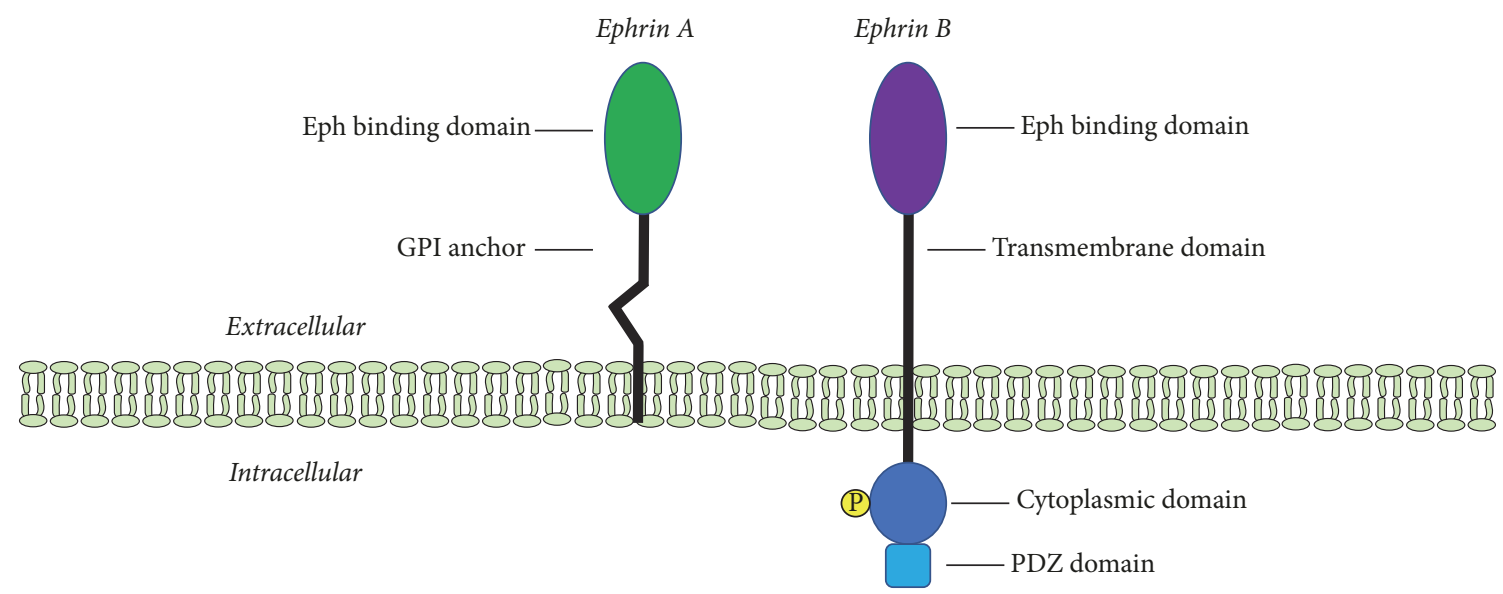

FIgURE 2: Structure of Ephrin Ligands. The GPI anchor and transmembrane domains of ephrin-A and ephrin-B are shown. Both classes have Eph binding domain on the extracellular side. Ephrin-B contains a cytoplasmic domain and a PDZ domain.

tyrosine residues, a kinase domain, a sterile $\alpha$ motif (SAM) protein-protein interaction domain, and a C-terminal PDZbinding motif [17-19]. The arrangement of these domains and motifs in Eph receptors is schematically represented in Figure 1. These domains and regions contribute to the $3 \mathrm{D}$ topology of the protein and facilitate its interaction with other proteins within the cellular signaling network. Phosphorylated amino acid residues in the activated Eph receptors mediate these interactions. However, EphA10 and EphB6 lack kinase activity due to altered sequence of the conserved regions within the kinase domain [20].

Eph receptors are activated by binding of ephrin ligands to the ephrin-binding domain in the receptor. The Eph binding domain of the ephrin ligand is attached to the plasma membrane by a linker segment of variable length [17]. The two classes of ligands are distinguished by the presence of GPI anchor in ephrin-A ligands and a transmembrane segment in ephrin-B ligands [21]. The structural features of the two classes of ephrins are illustrated in Figure 2.

\section{Physiological Roles of Eph Receptors and Ephrin Ligands}

The spatial organizations of Eph receptors and ephrin ligands require the presence of these molecules on the surface of two interacting cells of the same or different types. Thus, physical 
contact is necessary for initiating forward and/or reverse signaling in different cell types. Such contact-mediated physiological functions of these receptor-ligand pairs have been extensively documented for axon guidance, neuronal development, vascular patterning, and wound healing as described below.

3.1. Axon Guidance. Axons in the nervous system extend over long distances to reach their targets, and this process is facilitated by Eph receptors and ephrins. Attraction or repulsion of growth cones, which are large actin-supported extensions of a growing neurite, modulate axonal spread [112]. Interactions of ephrin-As with TrkB and p75 neurotrophin receptor lead to axon pathfinding and elongation via reverse signaling [113]. Ephrin-Bs recruit cytoskeleton regulators for axon guidance, dendrite morphogenesis, and postsynapse maturation [113]. While several other important molecules such as Zic2, neuropilin-1 (NRP1), and NrCAM are involved in guiding retinal ganglion axons, induction of EphB receptors by Zic2 transcription factor substantiate the central role of Eph/ephrin signaling in axon guidance during neurogenesis [114-119].

3.2. Neural Development. Neural progenitor cell proliferation, neuroblast migration, neuron survival, and neuronal plasticity also depend on Eph-ephrin interactions. The activation of EphB1, EphB2, EphB3, and EphA4 by ephrin ligands leads to migration of neuroblasts in the subventricular zone of the lateral ventricles in the adult mammalian brain [120]. Ephrin-A5 is required for the survival of newborn neurons in adult mice hippocampus, proliferation of cells in the hippocampal dentate gyrus, and the regulation of vasculature within the hippocampus [121]. Eph/ephrins also act as negative modulators in the nervous system as shown by the involvement of EphA7 and ephrin-A2 on progenitor cell proliferation in mice [122], influence of ephrin-B3 [123], and EphB3 [124] in the adult subventricular zone, and regulation of hippocampus neural progenitor growth by ephrin-A2/A3mediated activation of EphA7 [125]. Thus, activation of Eph receptors by ephrins is critical for the maintenance, proliferation, and inhibition of neural progenitors during neurogenesis.

3.3. Vascular Development. EphB4 and ephrin-B2 are known for their roles in dorsal aorta and cardinal veins. The endothelial cells in the artery are marked by ephrin-B2, while EphB4 marks venous endothelial cells [126]. The interaction of ephrin-B2 in artery and Eph receptor in veins is indicative of their roles in defining boundaries between veins and arteries [127]. These observations are also confirmed by zebra fish model of vascular development [128] and mouse retinal system $[129,130]$.

The lymphatic vasculature, a branched network of blindended capillaries and collecting lymph vessels [131], requires EphB4 and ephrin-B2 to develop vascular valves to regulate unidirectional flow within the lymphatics [132]. Involvement of ephrin-B2 has been confirmed by its ability to induce VEGFR3 internalization [129] as well as lymphatic system remodeling $[102,133]$. Ephrin-B2 is also necessary for blood vessel network stabilization $[134,135]$.

3.4. Tissue Injury. The healing of injured or inflamed vessels occurs by platelet plug formation and coagulation of extravasated blood. This process involves signaling pathways that facilitate the recruitment of inflammatory cells and proliferation of fibroblasts and epithelial cells. Eph/ephrin proteins partake in tissue healing as regulators of angiogenesis [19] and cell migration [136]. Eph/ephrin regulation has also been observed in renal ischemic injury [137]. Upregulation of Eph/ephrin expression in hypoxic mouse skin flap models supports the hypothesis of Eph/ephrin involvement in ischemic tissue injury repair [138]. Similarly, remodeling events following optic nerve injury in EphB3 null rodents resulted in decreased axon sprouting due to impaired interaction between macrophages and retinal ganglion cell axons [139]. Lastly, immunochemistry data showed EphB3 overexpression in invading fibroblasts and ephrin-B2 expression in astrocytes during spinal cord injury [140]. EphA4 has been implicated in the formation of astrocytic gliosis and scar formation following spinal injury in rodents and nonhuman primates [141, 142]. These observations indicate Eph/ephrin involvement in the events that follow tissue injury.

\section{Eph/Ephrin Signaling System}

Eph receptors constitute the largest family of receptor tyrosine kinases (RTK). Several features of the Eph-ephrin family distinguish it from other RTK families. RTK are activated by binding to soluble ligands, but Eph RTK bind to ephrin ligands attached to the plasma membrane of an opposing cell. Activated RTK exist as dimers, and activated Ephephrin signaling system exists as higher order clusters [143, 144]. The formation of multimeric structures by high affinity binding between Eph and ephrins may lead to repulsion of cells [144]. The repulsion between two cells is attributed to the cleavage of the ephrin ligand as demonstrated by the association of ADAM10 metalloprotease with EphA3 and cleavage of ephrin-A5 following its binding with EphA3 [145]. Alternatively, endocytosis of Eph-ephrin complexes by Racmediated actin cytoskeletal reorganization can also cause contact-mediated repulsion [146, 147]. Lastly, ephrins have the potential to elicit reverse signaling within ephrin-bearing cells $[148,149]$. Although the physiological relevance of Ephephrin clustering is not clearly understood, it appears to determine the strength of kinase activity and the cellular response [145].

Trans-interaction between Eph receptors and ephrin ligands on opposite cells activates forward and reverse signaling. Coexpressions of EphA receptors and ephrins in their cis-interactions lead to inhibition of trans-interaction signaling [148, 150, 151]. Figure 3 summarizes the generic transactivation processes in forward signaling mediated by Eph receptors and reverse signaling mediated by ephrin ligands [113]. The figure also illustrates cis-inhibition caused by coexpression of Eph receptors and ephrin ligands in the same cell. While forward signaling involves Rho GTPases, 


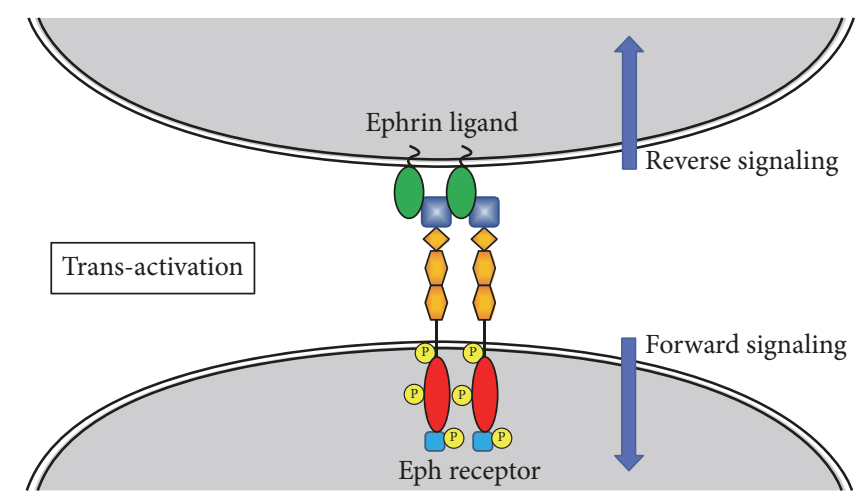

(a)
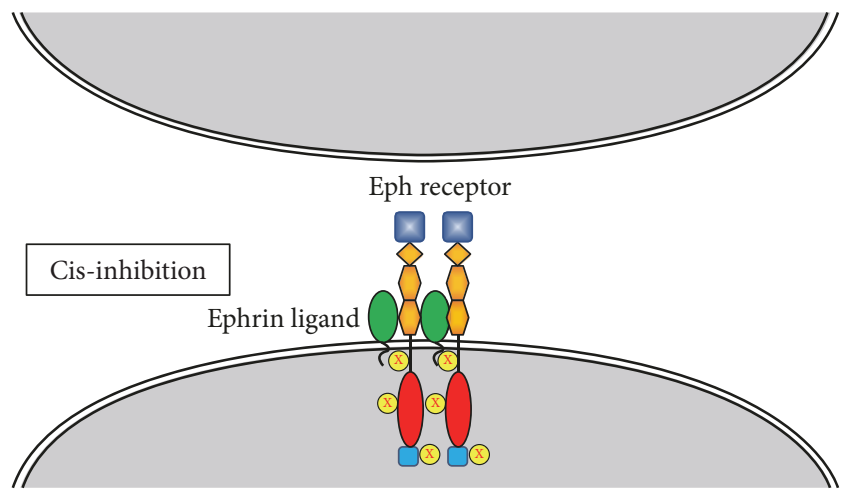

(b)

FIGURE 3: Eph/Ephrin Forward/Reverse Signaling and Cis-Inhibition. (a) Ephrin ligand and Eph receptors expressed on opposite cells are in trans-configuration. Both Eph receptor and ephrins activate bidirectional signaling - forward signaling with Eph receptors and reverse signaling with ephrin ligands. The activation is depicted by the presence of phosphorylated residues in the receptor. (b) Coexpression of EphA family receptor and ephrin-A family ligand on the same cell results in a cis-configuration. Such arrangement impairs Eph receptor activation and prevents trans-interaction. The inactive receptor is indicated by the lack of phosphorylated residues.

reverse signaling is mediated by Src kinases as described below. A heterotetrameric structure is formed after binding of ephrin ligands to the glycosylated ligand binding domain of the Eph receptor, leading to the activation of the tyrosine kinase domain and subsequent phosphorylation of specific tyrosine residues [143, 152]. Activated Eph receptors recruit phosphotyrosine-binding adapters to activate Rho GTPases such as RhoA, Cdc42, and Rac for actin cytoskeleton remodeling [16]. Rho GTPases function as molecular switches that cycle between an inactive (GDP-bound) and an active (GTPbound) state. Guanine nucleotide exchange factors (GEF) and GTPase-activating proteins (GAP) regulate the relative abundance of active and inactive Rho proteins [153]. Reverse signaling in ephrin-bearing cells begins with clustering of the ligand to promote the recruitment and activation of Src family kinases which phosphorylate specific tyrosine residues of the ligand's cytoplasmic domain [154]. The phosphorylated ligand provides a docking site for Grb4 and alters cytoskeletal dynamics by a variety of pathways triggered by several proteins such as $\mathrm{Cbl}$ associated protein (CAP/ponsin), Abelson interacting protein 1 (Abi-1), dynamin, paxillin, FAK, PAK1, hnRNPK, and axin [155]. Ephrin-B containing cells, on the other hand, mediate reverse signaling by recruiting intracellular adapter proteins to the phosphotyrosine residues in the cytoplasmic domain and the carboxyterminal PDZbinding motif [156].

\section{Eph/Ephrin Signaling in Cancer}

The overexpression of several Eph receptors/ephrin ligands and downregulation of a different set of Eph/ephrin molecules in a variety of tumors suggest that these proteins have growth promoting and growth suppressing activities. Despite the challenges of resolving the complexity of Eph/ephrin signaling pathways within cancer cells, Eph receptors and ephrin ligands remain attractive targets for cancer therapy. We focus here on the mechanisms underlying the upregulation/downregulation of Eph receptors and ephrin ligands in lung, breast, brain, prostate, and colorectal cancer.

\section{Lung Cancer}

Lung cancer is the leading cause of cancer mortality in the world, with more deaths than colorectal, breast, and prostate cancer combined, and smoking is the most important risk factor in the development of pulmonary carcinomas [157]. Non-small cell lung cancer (NSCLC), a highly invasive and aggressive carcinoma, accounts for approximately $80 \%$ of all lung cancers [158]. The 5-year survival rate remains less than $15 \%$ despite the development of new surgical procedures and chemotherapeutic protocols $[157,158]$.

EphA2 is one of the most frequently examined Eph receptors in pulmonary carcinomas. Similarly, its ligand ephrin-A1 [159] has also been investigated in lung cancer [160, 161]. Overexpression of EphA2 in NSCLC and its correlation with smoking and metastasis [23] have been replicated in cultured bronchial airway epithelial cells (BAEpC). These studies also suggested an association of EphA2 with Ecadherin, Erk1/Erk2, p53, and JNK-MAPK pathway [24]. Overexpression of EphA2 in NSCLC patients also correlates with brain metastasis [25], and EphA2 invasive signals have been attributed in some cases to G391R mutation and consequent phosphorylation of two serine residues within mTOR [26]. The therapeutic potential of EphA2 is evident from its elevated expression in lung cancer cells that are resistant to EGFR tyrosine kinase inhibitor (TKI) and decreased viability of these resistant cells by pharmacological inhibition of EphA2 [27]. Other studies that demonstrate upregulation of ephrin-A3 in NSCLC [29] and inhibitory effects of ephrin-A3 and ephrin-B2 on transactivation of EphA2/EphA3 and EphA3/EphB4, respectively, are indicative of context-dependent aberrations of Eph/ephrin molecules in cancer cells $[29,30]$. The induction of EphA3 overexpression in chemoresistant lung carcinoma cells in vitro has been shown to decrease chemotherapy resistance and enhance apoptosis by affecting phosphorylation of specific proteins constituting the PI3K/BMX/STAT3 signaling pathway [162]. Moderate-to-high levels of EphA4, EphA5, or EphA7 have 
been associated with longer survival in NSCLC patients. The combined expression of EphA1, EphA4, EphA5, and EphA7 has been used to distinguish various stages of lung cancer [22].

Among the B class of Eph/ephrins, EphB3, EphB4, ephrin-B1, and ephrin-B3 have been investigated in lung carcinoma. EphB3 overexpression is linked to clinical features of tumors and accelerated growth characteristics [31]. While in vivo loss of EphB3 led to activation of capase-8 and apoptosis, ligand dependent activation of EphB3 suppresses NSCLC metastasis. Mechanistically, EphB3 appears to decrease Akt activity via formation of PP2A/RACK1/Akt signaling complex [32]. Although EphB4 overexpression affects proliferation, colony formation, and motility in vitro, paradoxically there is a positive correlation between EphB4 expression and patient survival [33]. Cross-talk between ephrins and Eph receptors and activated status of Eph receptors have also been demonstrated by phosphoproteomic profiling of NSCLC cells. These investigations revealed that EphA2 stabilization occurs by phosphorylation of Akt in ephrin-B3 deficient NSCLC cells, and increased EphA2 correlates with worse metastatic prognosis $[23,28]$. EphB6 has been shown to be prognostic indicator for NSLC [163], and deleterious mutations in this protein have also been characterized in primary tumor specimens obtained from NSLC patients [164]. Table 1 summarizes alterations in representative receptors and ligands reported by various laboratories with a tentative mechanism associated with these changes.

\section{Breast Cancer}

Eph receptors and ephrin ligands are important for mammary epithelial morphogenesis. These proteins are expressed in tumor cells as well as the tumor microenvironment, and their abundance is altered in breast carcinoma cells. We have described the following alterations in the levels of Eph receptors in breast cancer cells and briefly discussed the mechanisms underlying the expression of specific members of the Eph receptor family and their diagnostic/prognostic relevance.

EphA2 and EphB4 are the two most extensively studied receptors in breast carcinomas [23]. EphA2 is overexpressed in a majority of breast tumors, can transform normal breast cells, and is known to have both pro- and antioncogenic properties [34, 36, 165, 166]. Furthermore, expression of kinase-deficient variants of EphA2 in breast cancer cells led to decreased tumor volume and increased tumor cell apoptosis [167]. In vivo studies have demonstrated that chronic trastuzumab treatment results in the phosphorylation of EphA2 through Src kinase, causing the activation of PI3K/Akt and MAPK pathways, which lead to trastuzumab resistance [12]. Some effects of EphA2 on tumor phenotypes are mediated by its physical and functional interaction with ErbB2/EGFR and activation of signaling pathways that involve Ras/MAPK and RhoA [35]. At cellular level, the phosphoprotein Anks1 promotes tumorigenesis by facilitating export of EphA2/ErbB2 complexes into COPII vesicles [13]. An inverse relationship between EphA2 and estrogen dependence has been observed in breast cancer cells both in vivo and in vitro, and decreased tamoxifen sensitivity was noticed in estrogen receptor (ER) positive breast cancer cells with EphA2 overexpression [168]. Exposure of ER+ breast cell lines to paclitaxel or doxorubicin also leads to increased expression of EphA2 [169]. Microarray analyses have shown a negative correlation of EphA2, EphA4, and EphA7 expression with overall survival [36]. Physical interaction of EphA7 with EphA10 [37], a kinase null receptor [46], may provide mechanistic aspects of the involvement of various Eph receptors in tumorigenesis in a context-dependent manner. Such interactions become important to explain the correlation of EphA10 expression with lymph node metastasis in breast cancer patients [38].

Among EphB receptors, EphB4 has been shown to be upregulated as well as downregulated in breast cancer cells [41, 170, 171], and knockdown of EphB4 inhibits tumor cell viability. These observations suggest EphB4 to be performing both pro- and antioncogenic roles. EphB4 expression is induced by EGFR, and inhibitors of JAK-STAT and PI3K-Akt pathways abolish EGFR induced upregulation of EphB4 receptor [41]. While antioncogenic EphB4/ephrinB2 effects are mediated by activation of Abl-Crk pathway and downregulation of matrix metalloprotease MMP-2 [42], its tumor promoting effects manifest via ligand-independent phosphorylation [51, 52]. Additional support for EphB4 and ephrin-B2 involvement in breast cancer is provided by PP2A (protein phosphatase) knockdown effects on ERK pathway in ephrin-B2 stimulated cells [43] and morphological changes in mammary gland as well as aberrant expression of $\mathrm{E}$ cadherin in mutant ephrin-B2 transgenic mice [44]. The underlying mechanism of ephrin-B2 and inappropriate Ecadherin expression may be partly explained by interactions of EphB receptors with metalloproteinase ADAM10, and subsequent E-cadherin shedding [45].

EphB6, a kinase null receptor [172] with a high affinity for ephrin-B1 and ephrin-B2 [50], has been investigated extensively for its role in breast tumorigenesis. Binding of ephrin$\mathrm{B} 1$ or ephrin-B2 to EphB6 leads to its heterodimerization with EphB1, which is followed by the phosphorylation of kinase null EphB6 [46, 47]. Upon phosphorylation, EphB6 interacts with c-Cbl to promote breast tumor cell motility [48]. EphB6 expression exists in normal mammary gland and noninvasive breast tumor cell lines, but it is downregulated or absent in invasive metastatic breast cancer cell lines [173]. Levels of EphB6 are regulated by methylation of its promoter sequence in a cell-specific manner [49]. The application of methylationdependent regulation of EphB6 expression is further evident in an investigation utilizing MSP (methylation-specific polymerase chain reaction) for potential detection of breast tumor cells in circulation [174]. Molecular and phenotypical changes in breast cancer cells appear to involve EphB6 cross-talk with cadherin 17, and altered expression of EphB6 influences WNT pathway [15]. It is noteworthy that while EphB6 has been considered a tumor suppressor in cell line models of breast tumorigenesis [15, 39, 48, 49, 173-175], its association with reduced survival in breast cancer patients has also been reported [36].

The signals transduced by the kinase-deficient EphB6 are dependent on its ability to form heterodimers with EphA2 


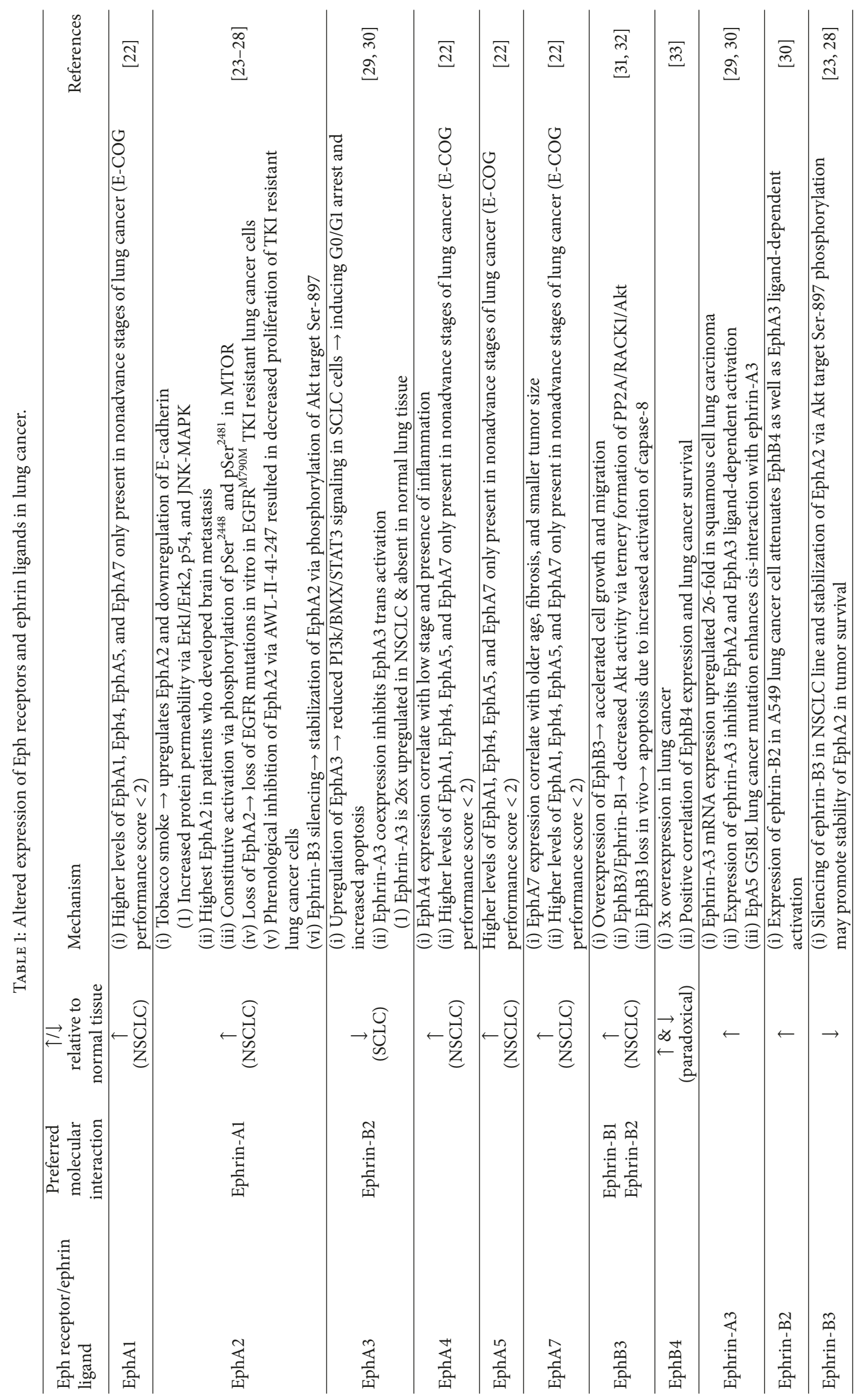


and EphB2 [39]. Given the overexpression of EphA2 in breast cancer cells, tumor suppressor action of EphB6 may be explained by its heteromerization with EphA2 [39]. A recent study indicates the association of EphB2 expression with breast cancer survival [40]. These observations are clear indications of context-dependent biological relevance of various Eph receptors and ephrin ligands. Table 2 summarizes altered abundance of Eph receptors and ephrin ligands with the characteristics of breast carcinoma cells.

\section{Brain Cancer}

Eph receptors have been extensively studied in glioblastoma multiforme (GBM), a subgroup of gliomas, and the pediatric brain tumor known as medulloblastoma [176-178]. While gliomas arise from astrocytes and oligodendrocytes [176, 177], medulloblastoma originate from granule neuronal precursor cells in the cerebellum or neural stem cells of the rhombic lip [178]. The migratory and invasive cell phenotype of medulloblastoma cells allow them to rapidly disseminate along leptomeningeal surfaces [179]. The involvement of Eph receptors in these two important brain neoplasms is described below.

8.1. Glioblastoma. EphA2 is highly expressed in GBM but not in normal brain as demonstrated by 100 -fold higher levels of EphA mRNA in human GBM specimens compared to normal brain tissue $[53,180]$. Particularly, EphA2 supports tumor-propagating cells with stem-like characteristics to remain in an undifferentiated state in human GBM. This has been demonstrated by the loss of self-renewal and induction of differentiation in vitro when EphA2 is silenced in human GBM cells via siRNA knockdown as well as ephrinA1-Fc ligand-induced EphA2 downregulation [53]. A positive correlation between EphA2 expression and pathological grade as well as proliferation has been observed in astrocytic tumors [181]. In addition, an inverse relationship exists between increased EphA2 expression and apoptosis [181]. Furthermore, a positive correlation with adverse clinical outcomes has been established with higher levels of EphA2 expression [182]. The molecular action of EphA2 in glioblastoma involves decreased Erk phosphorylation, Akt interaction, Sox downregulation, and altered invasiveness of stem cells [53-57]. These observations suggest that EphA2mediated regulation of stemness and that of invasiveness are partly responsible for glioma phenotypes [57]. Soluble ephrin-A1, a ligand for EphA2, can lead to internalization of EphA2 and alterations in GBM cell morphology, migration, and adhesion $[58,59]$. The tumorigenicity induced by EphA3, which is frequently overexpressed in the most aggressive subtype of GBM [61] but absent in normal brain tissue [62], is reduced by its ligand ephrin-A5 $[63,183]$. Such effects of ephrin-A5 are attributed to an increase in the ubiquitination and subsequent degradation of the EGFR after its binding to $\mathrm{c}-\mathrm{Cbl}$ [63]. Ephrin-A5 conjugated to a cytotoxin has been effective in killing GBM cells that overexpress EphA2, EphA3, and EphB2 receptors [62]. EphA3 transduces signal via MAPK pathway to maintain undifferentiated GBM cells and facilitates differentiation of neuronal progenitor cells [60,
61]. Though not well-characterized for their roles in GBM, altered expression of EphA4, EphA5, and EphA8 has been reported in GBM cells $[64-68,183]$. Preliminary observations in GBM cells reveal some of these receptors as modulators of proliferation or predictors of disease status and poor prognosis $[64,66,67,183]$.

The involvement of EphB receptors in GBM cell migration and invasion and tumor angiogenesis is evident from the observations that indicate both altered abundance and phosphorylation of EphB2 and overexpression of ephrin-B3 in invasive cell lines through activation of R-Ras and Racl [69, $70,75,76]$. EphB2 appears to function as a promigratory and antiproliferative molecule [71]. EphB2 is posttranscriptionally regulated by miR-204, which is downregulated in both glioma cells and neural stem cells. Given the ability of miR204 to target SOX4, it is suggested that altered abundances of SOX4 and EphB2 together are involved in modulating stemness and migration of glioma cells [72].

Ephrin-B2 together with its receptor EphB4 promotes angiogenesis via Notch and VGFR2 [184-186] and enhances migration and invasiveness of $\mathrm{U} 251 \mathrm{GBM}$ cells both in vitro and ex vivo [74]. Higher expression of ephrin-B2 and EphB4 in gliomas also correlates with worse clinical prognosis [73].

The changes in Eph receptors and ephrin ligands in gliomas reported in the literature are listed in Table 3. As evident from the table, altered abundance of these molecules is brought about by different mechanisms that in turn modulate a variety of signaling molecules and pathways.

8.2. Medulloblastoma. Eph receptors have been implicated in vasculogenic mimicry, invasion, migration, and signaling pathways operative in medulloblastoma. EphA2 expression, in particular, is associated with phosphoinositide 3-kinase (PI3K) and vasculogenic mimicry via metalloproteinase MMP-2 [77]. Elevated expression of EphA2, EphB2, and EphB4 in medulloblastoma cell line is linked to ephrinB1 mediated invasion [79]. The alterations in abundance and activation status of EphB2/ephrin-B1 correspond to changes in p38, Ras/Raf/Erk, PI3K, and Akt-mTOR signaling pathways $[79,187]$. It is therefore not surprising that EphB2 knockdown in medulloblastoma cells combined with radiation exposure led to significant reduction of cell viability and invasion [80]. While ephrin-B1 is uniquely dysregulated in medulloblastoma, differential effects of ephrin-B1 and ephrin-B2 knockdown on phosphorylation of EphB1/B2 and Src suggest alterations in reverse signaling in medulloblastoma cells [85]. The reduction in growth and increase in radiosensitivity of medulloblastoma cells by EphB1 knockdown further substantiate the involvement of this receptor in maintaining the tumor cell phenotype [78]. A noteworthy study also demonstrates a relationship between ephrin-A5 and medulloblastoma by using a mouse model. The genetic loss of ephin-A5, a ligand for EphA4 and EphA7, led to tumor growth inhibition in a genetically engineered mouse model that harbors Smoothened gene under the control of the NeuroD2 promoter [81]. These transgenic mice have a tissue specific constitutively active form of Smoothened, which regulates ephrin-A5 expression in the dorsal midbrain and hindbrain during embryonic development of mice and 


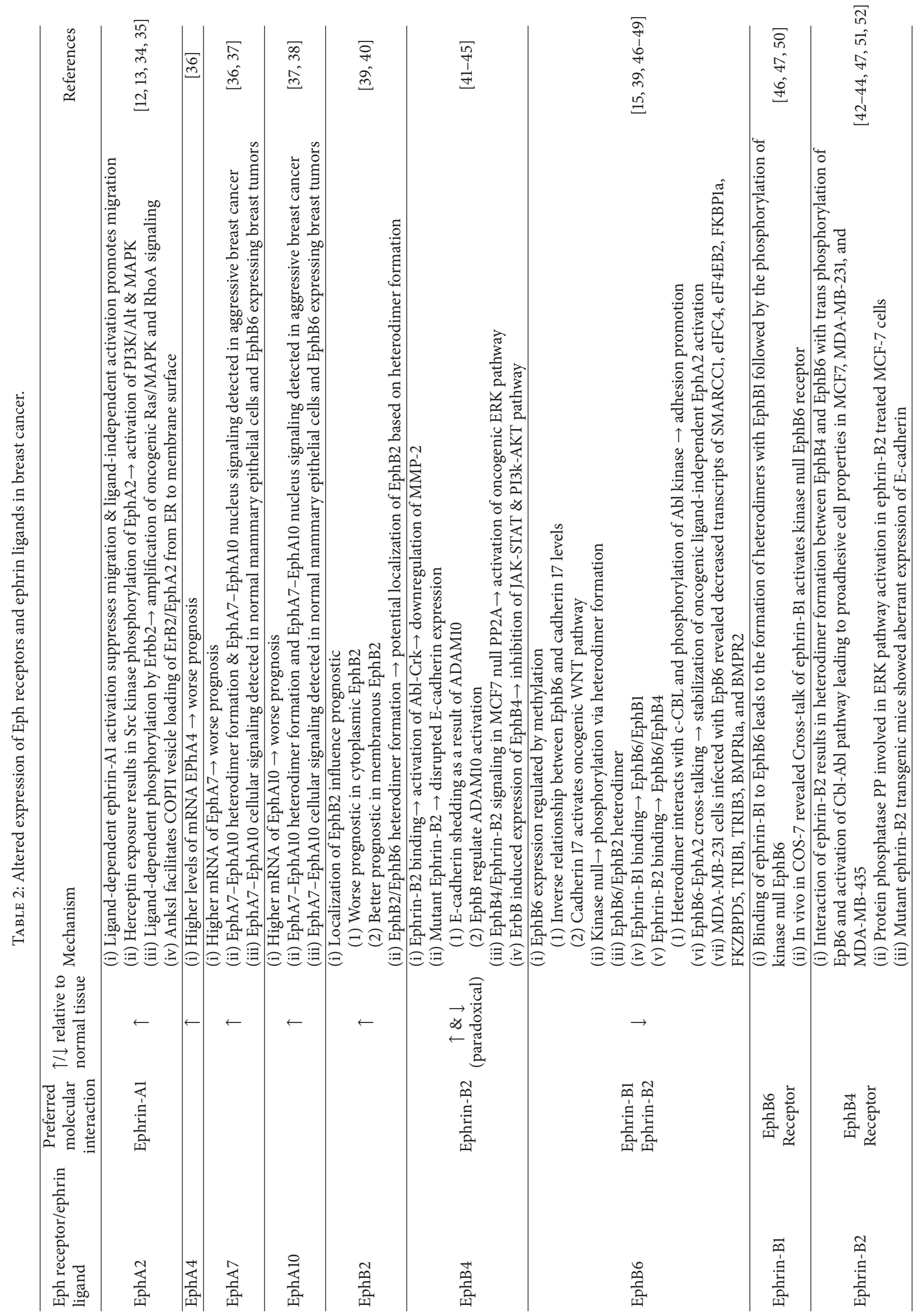




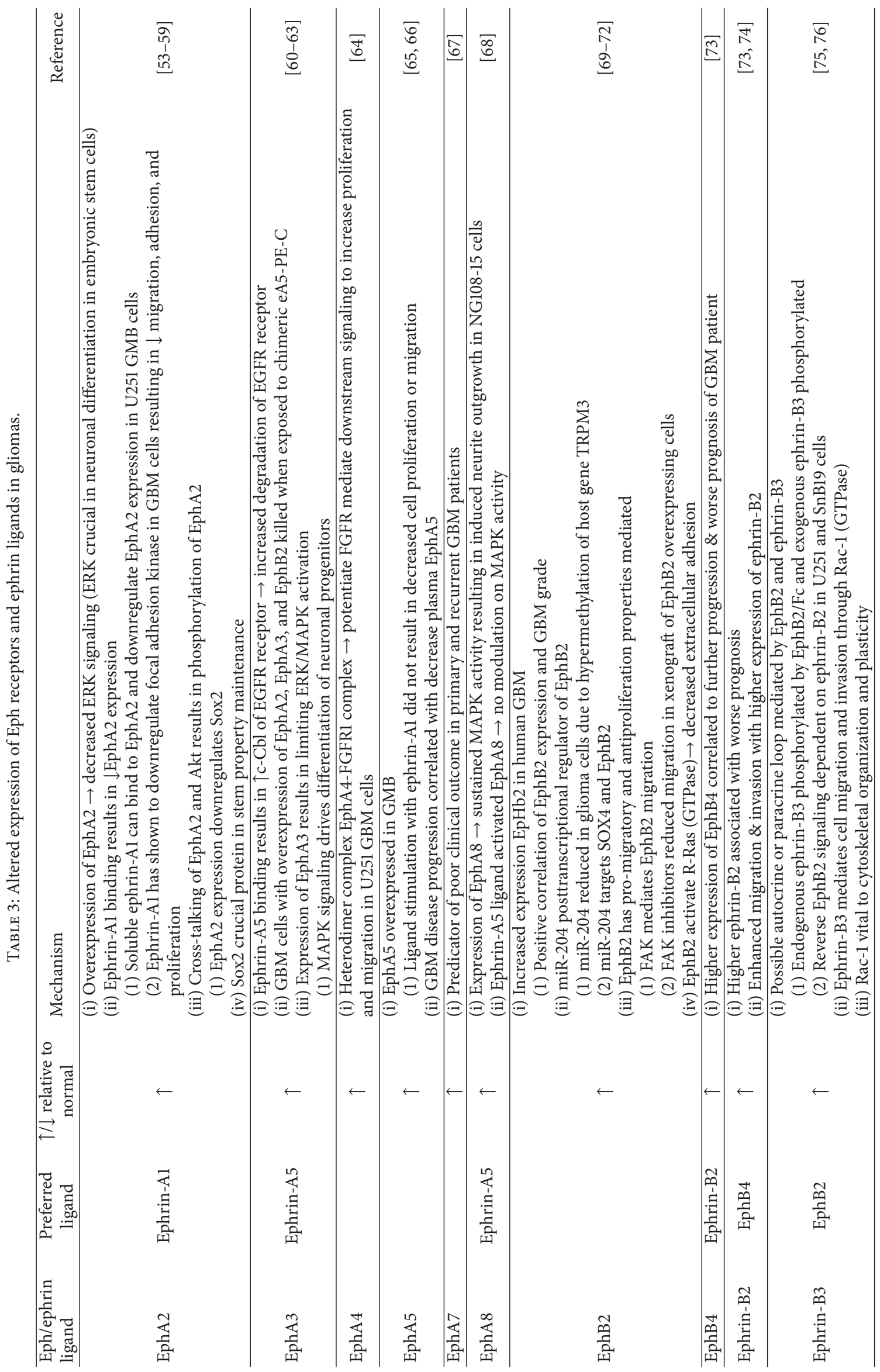


chick [81, 82]. The external granule cell layer, which acts as medulloblastoma precursor, shows overexpression of ephrinA5 [81, 83]. Molecular analysis of tumors isolated from engineered mice revealed the influence of ephrin-A5 on Akt, PI3K, and PTEN $[81,84,188]$.

Table 4 summarizes variations in the levels of Eph receptors and ephrin ligands in medulloblastoma. These changes disturb relevant pathways that modulate cell proliferation, vascular reorganization, cell cycle, and tumor development.

\section{Prostate Cancer}

Prostate cancer is the third leading cause of cancer mortality in American men. A major clinical challenge in prostate cancer is distinguishing between aggressive and nonaggressive tumors [189]. Serum PSA levels have been utilized as a biomarker for over 20 years for screening and clinical management of prostate cancer [190]. However, inherent limitations of PSA screening, including a lack of specificity, have led to overdiagnosis and overtreatment of prostate cancer. Eph receptors and ephrin ligands show promise as biomarkers in many cancers and are attractive potential molecular biomarkers as well as targeted therapeutic agents for prostate cancer.

In a study consisting of cell lines representing normal prostate epithelium, primary prostate tumor, and aggressive forms of prostate tumor, several members of the Eph family were upregulated, some were downregulated, and others were either absent or unaltered. While EphA1 abundance was decreased in prostate cancer cell lines, EphA2, EphA5, EphA6, EphA7, EphA8, and EphA10 levels were elevated in some of the prostate cancer cell lines as compared to the normal prostate cell line [86]. Similar to breast cancer, EphA2 is the most extensively studied EphA receptor in prostate cancer. Early studies identified EphA2 protein overexpression in prostate cancer cell lines with greater metastatic potential, while normal and benign prostate tumor cells showed weak or no staining with EphA2 antibody [191]. A tumor grade specific increase in EphA2 protein has also been observed [87]. Stimulation of benign prostate epithelial cell line pRNS-1-1 with a soluble form of ephrin-A1 leads to decreased proliferation [192], and activation of EphA2 in PC3 cells decreases cell migration [193]. Furthermore, stimulation of EphA2 by ephrin-A1 in PTEN null PC3 cell line demonstrated inhibition of the Akt-mTORC1 pathway $[34,187,194]$. Transfection of PC3 cells with kinase-deficient mutant forms of EphA2 showed reduced metastasis when compared to PC3 cells with overexpression of native EphA2 [195]. While EphA2 dependence on ephrin ligand manifests varied phenotypic effects [192-194], overexpression of EphA2 is related to induction of metastasis [196]. It appears from these observations that EphA2 effects manifest in a contextdependent manner.

Upregulation of EphA3 in androgen independent prostate cancer cells compared to androgen dependent prostate cancer cells has been observed by microarray analysis [89], and a tentative relationship between mutant AMP-activated protein kinase (AMPK) and upregulation of EphA3 mRNA has been proposed [90]. An increase in EphA4 mRNA and protein levels has been reported when prostatic intraepithelial neoplasia progresses to prostate carcinoma, and knockdown of EphA4 has shown altered viability and colony forming ability of cancer cells [91]. In a separate study, EphA4 stimulation by ephrin-A5 resulted in inhibition of PC3 cell migration by impairment of cell-cell contact [88]. The linkage of EphA4 with prostate cancer associated receptor ERBB3/HER3 [92] is apparent from the observed decrease of EphA4 transcript following the knockdown of ERBB3 in DU145 cells [92].

The EphA receptors that are decreased or lost in prostate cancer include EphA5 in patients with a Gleason score of 8 [197], EphA6 in LNCaP-19 cell line [198], and EphA7 in prostate tumor specimens [199]. Transcriptional silencing of EphA7 in a subset of prostate cancer cells is regulated by methylation of the EphA7 promoter [199]. The presence of EphA7 in primary tumors and its loss in lymph and bone metastases suggests that promoter methylation is perhaps not an early event in prostate cancer [200]. A recent genome sequence analysis has identified a single nucleotide polymorphism (rs731174) in an intron of the EphA10 gene that may interact with other SNPs to modify prostate cancer risk [201].

The prostate cell line panel has indicated a decrease in EphB2 with elevations in both EphB3 and EphB6 in some prostate carcinoma cells compared to normal prostate epithelial cells [86]. Specimens from metastatic prostate carcinoma showed missense and nonsense mutations in the kinase domain of EphB2, and transfection of normal EphB2 in DU145 cell line led to the suppression of growth and colony formation [93]. A higher frequency of a germline nonsense mutation termed K1019X (3055A > T) has been observed in African American men as compared to Caucasian men [202, 203]. Microarray and RT-PCR analysis of prostate cancer tissue have also identified differential expression of EphB3 [204]. Several studies indicate upregulation of EphB4 in the development and progression of prostate cancer [52, 205, 206].

The literature on ephrin alterations in prostate cancer is scarce. The cell line panel indicates increased abundance of ephrin-A1 and eprin-A2 in LNCaP and DU145 cells as compared to normal cells. Ephrin-B3 was detected at higher levels in all prostate carcinoma cell lines [86]. Microdissections of prostate carcinoma samples showed lower levels of ephrin-A1 mRNA in samples with Gleason score $>7$ and higher mRNA levels of ephrin-A1 from samples with Gleason score $<7$ [94]. In light of the decreased migration of prostate cancer cells upon stimulation of EphA2 with ephrin-A1, downregulation of ephrin-A1 in aggressive prostate cancers is not surprising. Increased levels of ephrin-A5 in LNCaP cell culture media after androgen exposure suggests androgeninduced release of ephrin-A5 from prostate cancer cells [95]. Additionally, an independent retrospective study on metastatic castration-resistant prostate cancer has reported a correlation of lower serum levels of ephrin-A5 with shorter survival time [96].

The significant alterations of Eph/ephrin profiles observed in prostate tumors and prostate cancer cell lines are listed in Table 5. It warrants mention that the molecular 


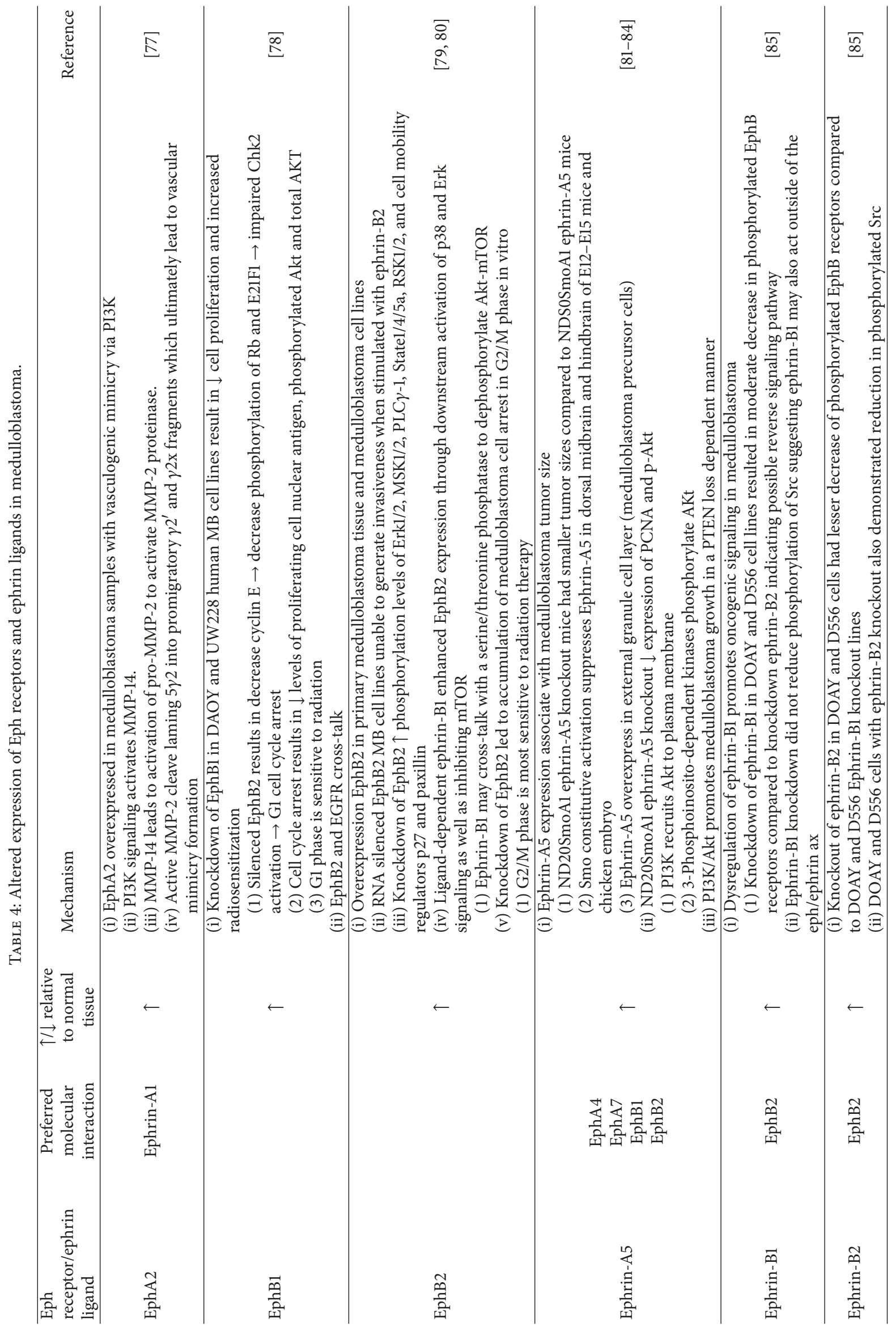




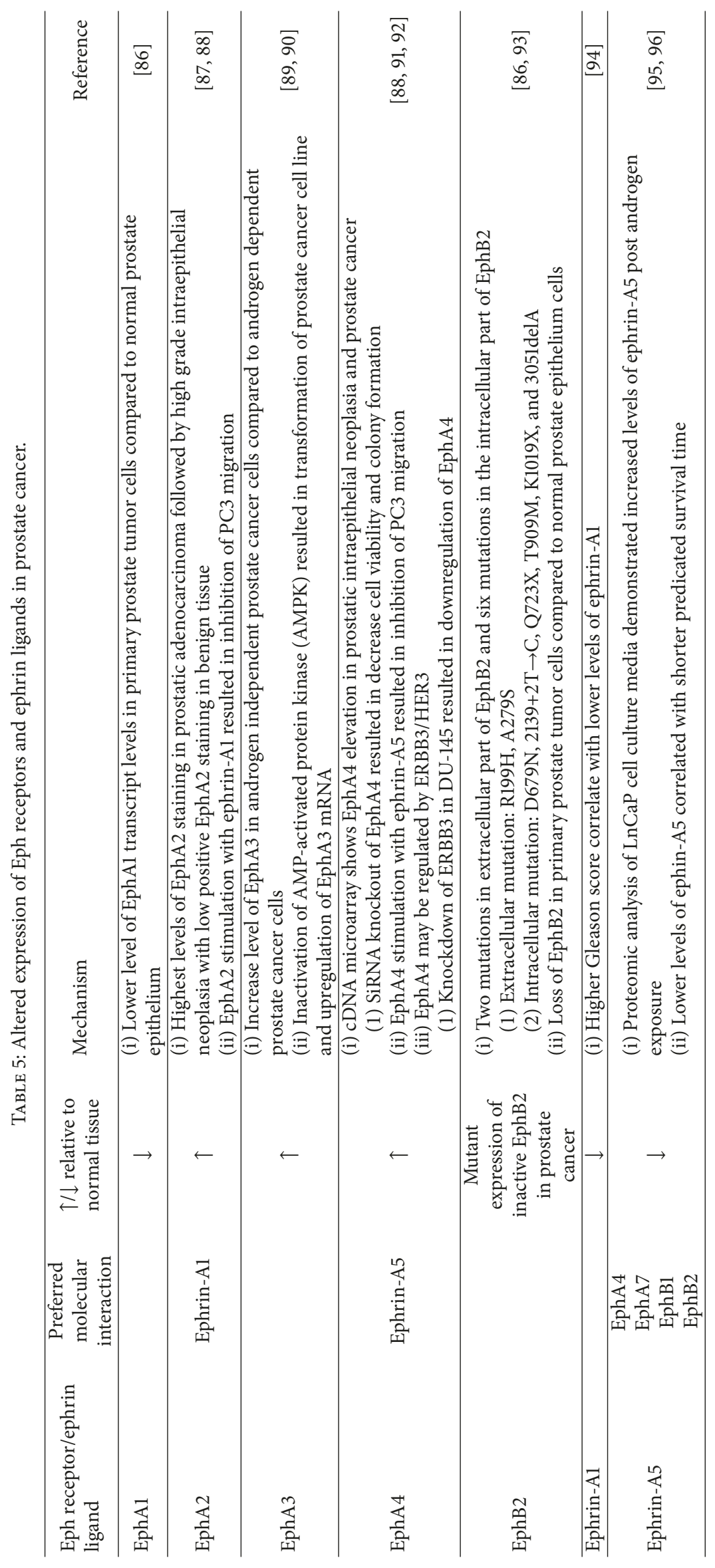


changes in prostate cancer cells are also responsive to their dependence on androgen.

\section{Colorectal Cancer}

Colorectal cancer (CRC) is the third most commonly diagnosed cancer in both men and women and is the fourth leading cause of cancer-related death worldwide [207]. About 5\% of CRC are monogenic, which include Lynch syndrome, familial adenomatous polyposis (FAP), MYHassociated polyposis, and rare hamartomatous polyposis syndromes [208]. Several Eph receptors and ephrin ligands exist as a gradient along the colon crypt axis of normal tissue [209]. While EphB1, EphB2, EphB3, EphB4, EphB6, EphA1, EphA4, and EphA7 are abundant in the basal crypt, the top of the crypt displays EphA2, EphA5, ephrin-A1, and ephrinB2 [209].

The relationship of elevated expression of EphB2 and EphB3 with abnormal migration of epithelial cells in the crypt villus junction in colon tumors of mice is suggestive of Eph receptor involvement in colorectal cancer [210]. Immunohistochemical analyses have revealed decreased abundance of EphA6, EphA7, and EphB1 in colorectal tumors [211]. The expression of EphB2, an important molecule responsible for correct positioning of epithelial cells in the crypt [209], is reduced in CRC $[212,213]$, and its higher expression is associated with prolonged survival of CRC patients [210, 213215]. The altered expressions of EphB2 and EphB4 in colorectal cancer have been explained by changes in adenomatous polyposis coli (APC) suppressor gene activity, CBP complex, and Wnt pathway $[104,105,216]$. Transcriptional silencing or downregulation of specific Eph receptors in CRC is associated with promoter methylation $[97,103,211]$. The activation of EphB3 in HT-29 human colon cancer cells inhibits epithelialto-mesenchymal transition via cell adhesion molecules [106, 107]. The elevated levels of EphB4 in CRC $[104,108]$ are being utilized for image guided colorectal surgery [109]. Although reduced abundance of EphB6 in CRC correlates with poor cell differentiation, advance disease, and poor prognosis [110], the mechanisms of EphB6 involvement in CRC are not well understood [111].

While the expression of EphA1 and EphA2 increases in early stages of CRC, the abundance of these receptors decreases in advanced stages of the cancer [97-99, 101]. The linkage of decreased EphA1 levels with higher invasiveness is supported by alterations in adhesion and motility of HRT18 CRC cells that had been rendered EphA1 null by gene knockout [100]. The alterations of Eph/ephrin profiles of colorectal tumors and cell lines described in this section are summarized in Table 6.

\section{Conclusion}

Based on the literature presented in this review, a composite network emerges that connects numerous pathways (Figure 4). This scheme was composed by adapting individual pathways described by other investigators [8-11]. The supporting data for other pathways and cross-talk among individual players is described in several publications, a few of which are cited here [12-16]. Thus, the involvement of Eph receptors and ephrin ligands in such a complex network illustrates aberrant regulation of these important molecules in tumorigenesis. It also suggests the mechanisms underlying cancer cell phenotypes associated with aberrant expression of Eph receptors.

The description presented in this review clearly demonstrates that elevated expression and/or loss of expression of specific Eph receptors are associated with either tumor growth or tumor suppression in a context-dependent manner. We suggest these consequences to arise by interaction of phosphorylated receptors with distinct intracellular proteins involved in pathways that either promote or inhibit cell proliferation and actin organization. The investigations on protein-protein interactions indicate that kinase-deficient Eph receptors, EphB6 and EphB10, can heteromerize with kinase sufficient receptors. Specifically, EphB6 heteromerizes with EphA2 and EphB2, and EphA10 interacts with EphA7 $[37,39]$. Such interactions in different contexts are likely to mediate different cancer phenotypes.

Mechanistically, cis-interaction of Eph receptors with ephrin ligands can inhibit transactivation-mediated tumor suppression activity $[30,150,217]$. Alternative mechanisms of tumorigenesis include activating oncogenic mutations or inactivating mutations in tumor suppressor functions of Eph receptors, regulation of epithelial-mesenchymal transition (EMT), control of motility and invasiveness, and alterations in Akt and MAP kinase pathways [26, 34, 57, 218-221]. All these modalities of transformation include Eph receptor functionality or lack thereof. EMT, a critical aspect of cell migration, accompanies ligand-independent signaling, while ligand-dependent forward signaling restores cell-tocell communication [219, 220]. A significant involvement of Eph receptors in tumorigenesis is based on their roles in regulating stemness of a subpopulation of cancer cells that are largely responsible for resistance to therapy [53, $61,222]$. In light of these observations, investigations on Eph receptor-mediated self-renewal of cancer stem cells are gaining momentum. The ability of Eph receptors to stimulate $\mathrm{T}$ cells has highlighted their importance in developing cancer immunotherapy [223-228].

The therapeutic applications of Eph receptors include monoclonal antibody targeting, soluble Eph fusion protein targeting, small molecule Eph kinase inhibitors, dendriticcell based vaccines, and siRNAs [10, 229-233]. However, these therapeutic modalities suffer from deficiencies such as varying effectiveness of antibodies, deleterious side effects, redundancy of functions, receptor-independent activation of signaling pathways, variable effects of Eph receptors in Tcell lineage development, and epigenetic regulation of Eph expression [61, 97, 229-241].

A potential therapy for cancer cells can be tailored around a synthetic Notch (synNotch), which would allow engineered cells to respond to multiple stimuli with distinct transcriptional programs [242]. Such engineered synNotch construct consisting of Eph/ephrin would be expected to emulate contact induced cis-inhibition in tumor cells. In 


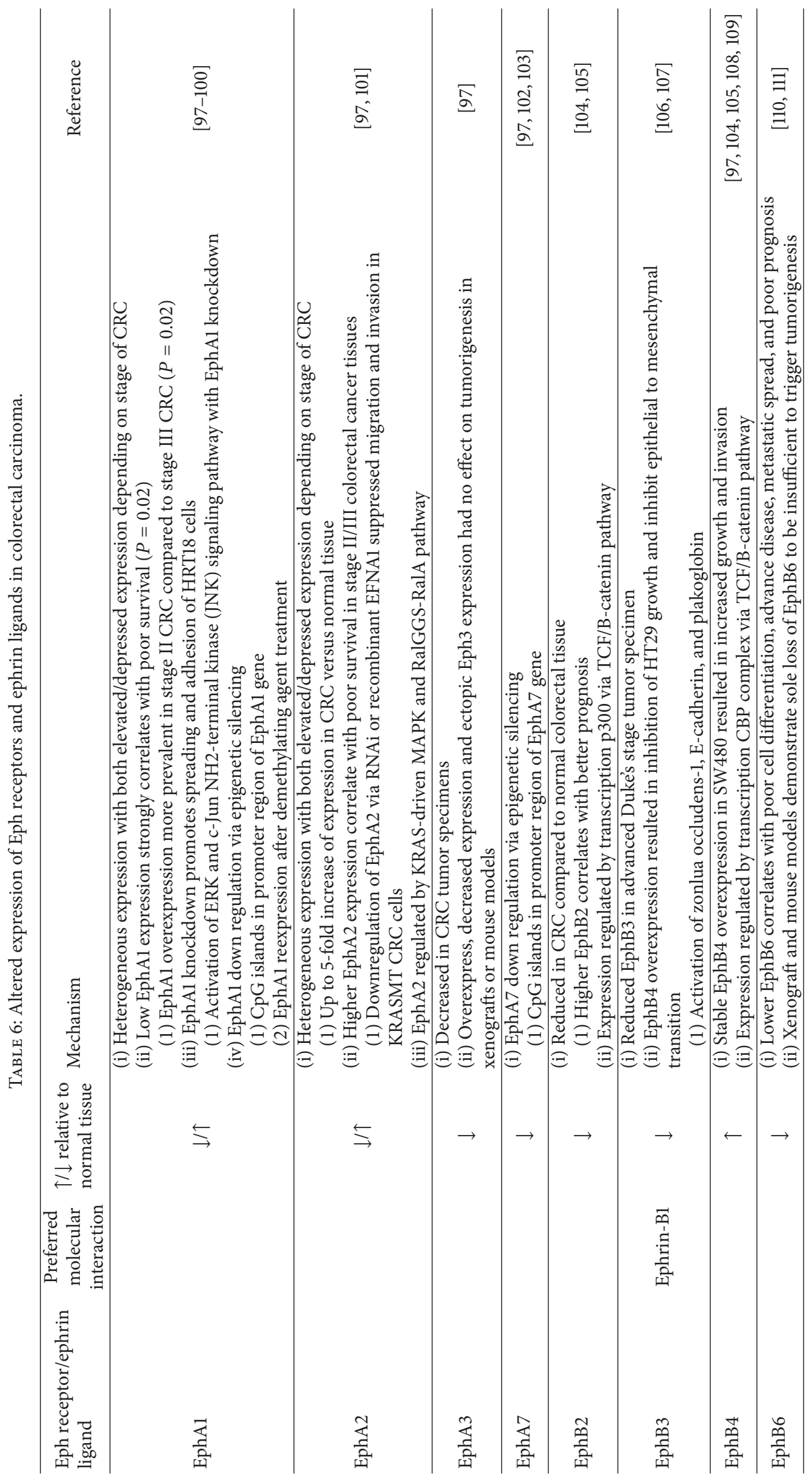




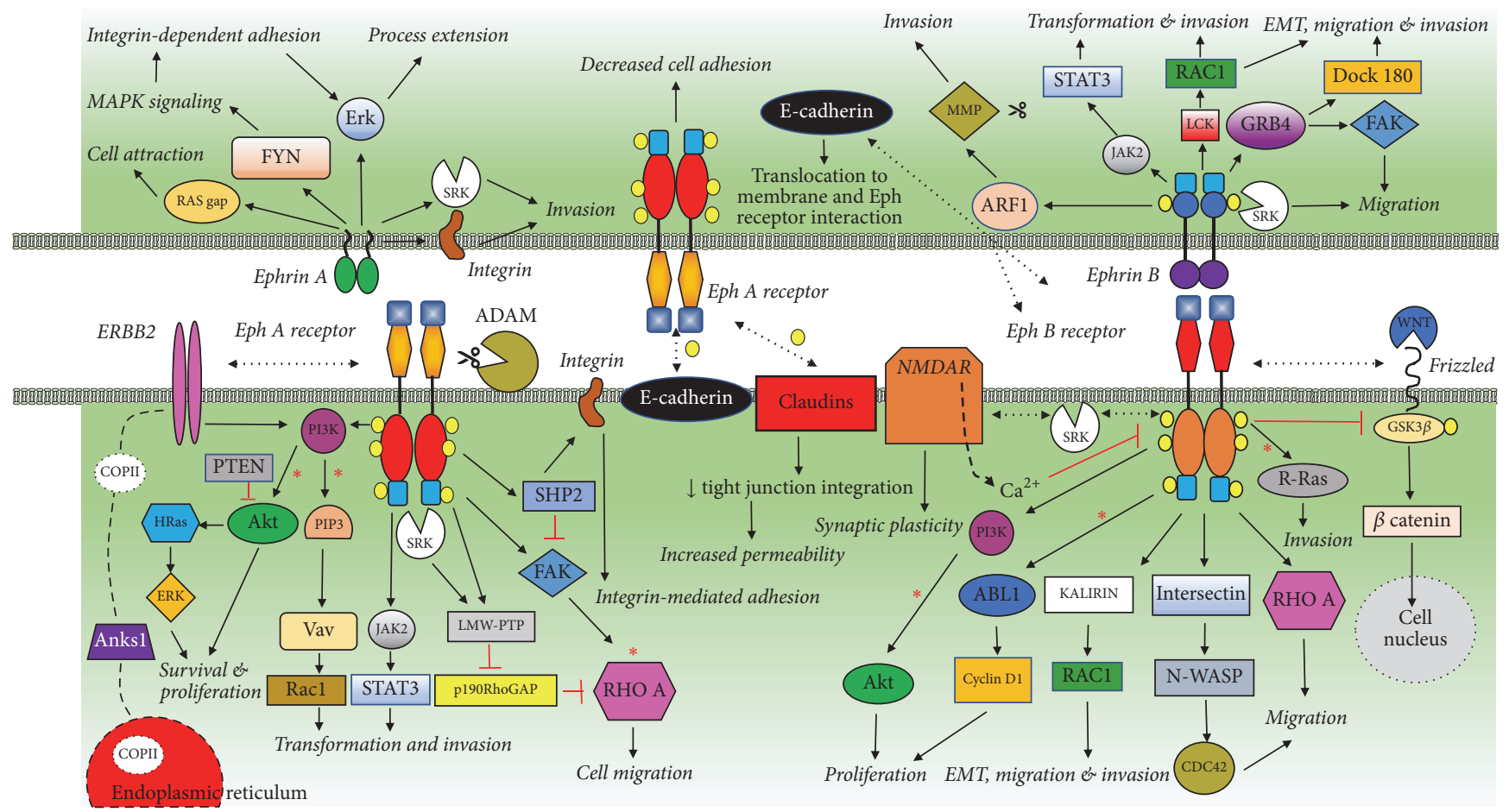

FIgure 4: Summary of Potential Eph/Ephrin Tumor Promoting Pathways. A composite scheme of major tumorigenesis promoting Eph/ephrin signaling pathways is shown together. Ligand-independent forward signaling tumor promoting pathways shown for EphA and EphB receptors. Forward signaling pathways marked with an asterisk are known to be inhibited in ligand-dependent manner and participate in tumor suppression. Reverse signaling pathways are also shown for ephrin A and ephrin B. Yellow circles indicate phosphorylation of specific tyrosine/serine/threonine residues that are required for pathway activation. The broken bidirectional arrow represents cross-talk between Eph/ephrin and other types of receptors or pathways. Scissors symbol represents expression and/or function of proteases such as ADAM or MMP that are involved in the regulation of EphA and ephrin-B pathways, respectively. EMT indicates epithelial-to-mesenchymal transition. The figure is adapted from representative publications of Pasquale [8], Lisle et al. [9], Boyd et al. [10], and Xi et al. [11]. In addition, some of the pathways are substantiated from observations presented in several reports in the literature related to trastuzumab [12], COPII vesicles [13], NMDA receptor [14], E-cadherin [14], WNT pathway [15], and claudins [14, 16] for their relevance to tumor promoting pathways.

light of the involvement of cancer stem cells (CSC) in metastasis [222] and the importance of Eph receptors in CSC maintenance [243], Eph/ephrins are important targets for therapeutic exploration. Illustrative examples of Eph receptors in stemness include the effects of EphA3 knockdown on GBM cell sphere formation [61] and the regulation of oncogenic Ras by EphA2 in transformed cells as well as expulsion of these cells from stem cell monolayer $[244,245]$.

The literature reviewed here clearly presents a common theme of tumorigenesis for various human cancers that involves a set of Eph receptors and ephrin ligands. Although some of these molecules appear to be facilitating similar processes in all cancers, the differences in the outcomes in certain situations may be attributed to the context and redundant expression of specific sets of Eph receptors and ephrin ligands. Further study in how mechanistically cancer cells initiate Eph cis-signaling, the role of Eph RTK in maintaining cancer-like stem cells within the microenvironment, and the extent of Eph functional redundancy may be beneficial in overcoming the challenges of developing targeted Eph therapy to combat the tumorigenic pathway.

\section{Conflicts of Interest}

The authors declare that there are no conflicts of interest regarding the publication of this paper.

\section{References}

[1] A. Y. Chow, "Cell cycle control by oncogenes and tumor suppressors: driving the transformation of normal cells into cancerous cells," Nature Education, vol. 3, no. 9, 7 pages, 2010.

[2] A. B. Harvey Lodish, S. Lawrence Zipursky, P. Matsudaira, D. Baltimore, and J. Darnell, "Proto-oncogenes and tumorsuppressor genes," in Molecular Cell Biology, W. H. Freeman, New York, 4th edition, 2000.

[3] G. M. Cooper, Tumor Suppressor Genes. The Cell: A Molecular Approach, Sinauer Associates, Sunderland (MA), 2nd edition, 2000.

[4] Y. Kiraz, A. Adan, M. Kartal Yandim, and Y. Baran, "Major apoptotic mechanisms and genes involved in apoptosis," Tumor Biology, vol. 37, no. 7, pp. 8471-8486, 2016.

[5] J. Folkman, "Tumor angiogenesis: therapeutic implications.", The New England Journal of Medicine, vol. 285, no. 21, pp. 11821186, 1971. 
[6] R. H. Adams and A. Eichmann, "Axon guidance molecules in vascular patterning.," Cold Spring Harbor Perspectives in Biology, vol. 2, no. 5, p. a001875, 2010.

[7] A. Barquilla and E. B. Pasquale, "Eph receptors and ephrins: Therapeutic opportunities," Annual Review of Pharmacology and Toxicology, vol. 55, no. 1, pp. 465-487, 2015.

[8] E. B. Pasquale, "Eph receptors and ephrins in cancer: bidirectional signalling and beyond," Nature Reviews Cancer, vol. 10, no. 3, pp. 165-180, 2010.

[9] J. E. Lisle, I. Mertens-Walker, R. Rutkowski, A. C. Herington, and S.-A. Stephenson, "Eph receptors and their ligands: Promising molecular biomarkers and therapeutic targets in prostate cancer," Biochimica et Biophysica Acta (BBA) - Reviews on Cancer, vol. 1835, no. 2, pp. 243-257, 2013.

[10] A. W. Boyd, P. F. Bartlett, and M. Lackmann, "Therapeutic targeting of EPH receptors and their ligands," Nature Reviews Drug Discovery, vol. 13, no. 1, pp. 39-62, 2014.

[11] H.-Q. Xi, X.-S. Wu, B. Wei, and L. Chen, "Eph receptors and ephrins as targets for cancer therapy," Journal of Cellular and Molecular Medicine, vol. 16, no. 12, pp. 2894-2909, 2012.

[12] G. Zhuang, D. M. Brantley-Sieders, D. Vaught et al., "Elevation of receptor tyrosine kinase EphA2 mediates resistance to trastuzumab therapy," Cancer Research, vol. 70, no. 1, pp. 299308,2010

[13] H. Lee, H. Noh, J. Mun, C. Gu, S. Sever, and S. Park, "Anksla regulates COPII-mediated anterograde transport of receptor tyrosine kinases critical for tumorigenesis," Nature Communications, vol. 7, Article ID 12799, 2016.

[14] D. Arvanitis and A. Davy, "Eph/ephrin signaling: networks," Genes \& Development, vol. 22, no. 4, pp. 416-429, 2008.

[15] L. Bhushan, N. Tavitian, D. Dey, Z. Tumur, C. Parsa, and R. P. Kandpal, "Modulation of liver-intestine cadherin (cadherin 17) expression, ERK phosphorylation and WNT signaling in EPHB6 receptor-expressing MDA-MB-231 cells," Cancer Genomics \& Proteomics, vol. 11, no. 5, pp. 239-249, 2014.

[16] N. K. Noren and E. B. Pasquale, "Eph receptor-ephrin bidirectional signals that target Ras and Rho proteins," Cellular Signalling, vol. 16, no. 6, pp. 655-666, 2004.

[17] E. B. Pasquale, "Eph-ephrin promiscuity is now crystal clear," Nature Neuroscience, vol. 7, no. 5, pp. 417-418, 2004.

[18] E. M. Lisabeth, G. Falivelli, and E. B. Pasquale, "Eph receptor signaling and ephrins," Cold Spring Harbor Perspectives in Biology, vol. 5, no. 9, pp. a009159-a009159, 2013.

[19] M. E. Pitulescu and R. H. Adams, "Eph/ephrin molecules - A hub for signaling and endocytosis," Genes \& Development, vol. 24, no. 22, pp. 2480-2492, 2010.

[20] J. M. Mendrola, F. Shi, J. H. Park, and M. A. Lemmon, "Receptor tyrosine kinases with intracellular pseudokinase domains," Biochemical Society Transactions, vol. 41, no. 4, pp. 1029-1036, 2013.

[21] E. B. Pasquale, "Developmental Cell Biology: Eph receptor signalling casts a wide net on cell behavior," Nature Reviews Molecular Cell Biology, vol. 6, no. 6, pp. 462-475, 2005.

[22] C. Giaginis, N. Tsoukalas, E. Bournakis et al., "Ephrin (Eph) receptor A1, A4, A5 and A7 expression in human non-small cell lung carcinoma: Associations with clinicopathological parameters, tumor proliferative capacity and patients' survival," $B M C$ Clinical Pathology, vol. 14, no. 1, article no. 8, 2014.

[23] D. M. Brantley-Sieders, "Clinical relevance of Ephs and ephrins in cancer: Lessons from breast, colorectal, and lung cancer profiling," Seminars in Cell \& Developmental Biology, vol. 23, no. 1, pp. 102-108, 2012.
[24] N. Nasreen, N. Khodayari, P. S. Sriram, J. Patel, and K. A. Mohammed, "Tobacco smoke induces epithelial barrier dysfunction via receptor EphA2 signaling," American Journal of Physiology-Cell Physiology, vol. 306, no. 12, pp. C1154-C1166, 2014.

[25] M. S. Kinch, M.-B. Moore, and D. H. Harpole Jr., "Predictive value of the EphA2 receptor tyrosine kinase in lung cancer recurrence and survival," Clinical Cancer Research, vol. 9, no. 2, pp. 613-618, 2003.

[26] L. Faoro, P. A. Singleton, G. M. Cervantes et al., "EphA2 mutation in lung squamous cell carcinoma promotes increased cell survival, cell invasion, focal adhesions, and mammalian target of rapamycin activation," The Journal of Biological Chemistry, vol. 285, no. 24, pp. 18575-18585, 2010.

[27] K. R. Amato, S. Wang, L. Tan et al., "EPHA2 blockade overcomes acquired resistance to EGFR kinase inhibitors in lung cancer," Cancer Research, vol. 76, no. 2, pp. 305-318, 2016.

[28] S. Ståhl, R. Branca, G. Efazat et al., "Phosphoproteomic profiling of NSCLC cells reveals that ephrin B3 regulates pro-survival signaling through Akt1-mediated phosphorylation of the EphA2 receptor," Journal of Proteome Research, vol. 10, no. 5, pp. 25662578, 2011.

[29] C. Hafner, "Differential Gene Expression of Eph Receptors and Ephrins in Benign Human Tissues and Cancers," Clinical Chemistry, vol. 50, no. 3, pp. 490-499, 2004.

[30] G. Falivelli, E. M. Lisabeth, E. R. De La Torre et al., "Attenuation of Eph receptor kinase activation in cancer cells by coexpressed ephrin ligands," PLoS ONE, vol. 8, no. 11, Article ID e81445, 2013.

[31] X.-D. Ji, G. Li, Y.-X. Feng et al., "EphB3 is overexpressed in non-small-cell lung cancer and promotes tumor metastasis by enhancing cell survival and migration," Cancer Research, vol. 71, no. 3, pp. 1156-1166, 2011.

[32] G. Li, X.-D. Ji, H. Gao et al., "EphB3 suppresses non-smallcell lung cancer metastasis via a PP2A/RACK1/Akt signalling complex," Nature Communications, vol. 3, article no. 667, 2012.

[33] B. D. Ferguson, R. Liu, C. E. Rolle et al., “The EphB4 receptor tyrosine kinase promotes lung cancer growth: a potential novel therapeutic target," PLoS ONE, vol. 8, no. 7, Article ID e67668, 2013.

[34] H. Miao, D.-Q. Li, A. Mukherjee et al., "EphA2 Mediates Ligand-Dependent Inhibition and Ligand-Independent Promotion of Cell Migration and Invasion via a Reciprocal Regulatory Loop with Akt," Cancer Cell, vol. 16, no. 1, pp. 9-20, 2009.

[35] D. M. Brantley-Sieders, G. Zhuang, D. Hicks et al., "The receptor tyrosine kinase EphA2 promotes mammary adenocarcinoma tumorigenesis and metastatic progression in mice by amplifying ErbB2 signaling," The Journal of Clinical Investigation, vol. 118, no. 1, pp. 64-78, 2008.

[36] D. M. Brantley-Sieders, A. Jiang, K. Sarma et al., "Eph/ephrin profiling in human breast cancer reveals significant associations between expression level and clinical outcome," PLoS ONE, vol. 6, no. 9, Article ID e24426, 2011.

[37] C. Johnson, B. Segovia, and R. P. Kandpal, "EPHA7 and EPHA10 physically interact and differentially co-localize in normal breast and breast carcinoma cell lines, and the co-localization pattern is altered in EPHB6-expressing MDA-MB-231 cells," Cancer Genomics \& Proteomics, vol. 13, no. 5, pp. 359-368, 2016.

[38] K. Nagano, S.-I. Kanasaki, T. Yamashita et al., "Expression of Eph receptor A10 is correlated with lymph node metastasis and stage progression in breast cancer patients," Cancer Medicine, vol. 2, no. 6, pp. 972-977, 2013. 
[39] B. P. Fox and R. P. Kandpal, "A paradigm shift in EPH receptor interaction: Biological relevance of EPHB6 interaction with EPHA2 and EPHB2 in breast carcinoma cell lines," Cancer Genomics \& Proteomics, vol. 8, no. 4, pp. 185-193, 2011.

[40] A.-M. Husa, Ž. Magic, M. Larsson, T. Fornander, and G. PérezTenorio, "EPH/ephrin profile and EPHB2 expression predicts patient survival in breast cancer," Oncotarget, vol. 7, no. 16, pp. 21362-21380, 2016.

[41] S. R. Kumar, J. Singh, G. Xia et al., "Receptor tyrosine kinase EphB4 is a survival factor in breast cancer," The American Journal of Pathology, vol. 169, no. 1, pp. 279-293, 2006.

[42] N. K. Noren, G. Foos, C. A. Hauser, and E. B. Pasquale, “The EphB4 receptor suppresses breast cancer cell tumorigenicity through an Abl-Crk pathway," Nature Cell Biology, vol. 8, no. 8, pp. 815-825, 2006.

[43] Z. Xiao, R. Carrasco, K. Kinneer et al., "EphB4 promotes or suppresses Ras/MEK/ERK pathway in a context-dependent manner," Cancer Biology \& Therapy, vol. 13, no. 8, pp. 630-637, 2012.

[44] M. Haldimann, D. Custer, N. Munarini et al., "Deregulated ephrin-B2 expression in the mammary gland interferes with the development of both the glandular epithelium and vasculature and promotes metastasis formation," International Journal of Oncology, vol. 35, no. 3, pp. 525-536, 2009.

[45] G. Solanas, C. Cortina, M. Sevillano, and E. Batlle, "Cleavage of E-cadherin by ADAM10 mediates epithelial cell sorting downstream of EphB signalling," Nature Cell Biology, vol. 13, no. 9, pp. 1100-1109, 2011.

[46] L. Truitt and A. Freywald, "Dancing with the dead: Eph receptors and their kinase-null partners," The International Journal of Biochemistry \& Cell Biology, vol. 89, no. 2, pp. 115-129, 2011.

[47] A. Freywald, N. Sharfe, and C. M. Roifman, “The kinase-null EphB6 receptor undergoes transphosphorylation in a complex with EphB1," The Journal of Biological Chemistry, vol. 277, no. 6, pp. 3823-3828, 2002.

[48] L. Truitt, T. Freywald, J. DeCoteau, N. Sharfe, and A. Freywald, "The EphB6 receptor cooperates with c-Cbl to regulate the behavior of breast cancer cells," Cancer Research, vol. 70, no. 3, pp. 1141-1153, 2010.

[49] B. P. Fox and R. P. Kandpal, “Transcriptional silencing of EphB6 receptor tyrosine kinase in invasive breast carcinoma cells and detection of methylated promoter by methylation specific PCR," Biochemical and Biophysical Research Communications, vol. 340, no. 1, pp. 268-276, 2006.

[50] P. Kaenel, M. Mosimann, and A.-C. Andres, "The multifaceted roles of Eph-ephrin signaling in breast cancer," Cell Adhesion \& Migration, vol. 6, no. 2, pp. 138-147, 2012.

[51] N. K. Noren, N.-Y. Yang, M. Silldorf, R. Mutyala, and E. B. Pasquale, "Ephrin-independent regulation of cell substrate adhesion by the EphB4 receptor," Biochemical Journal, vol. 422, no. 3, pp. 433-442, 2009.

[52] R. Rutkowski, I. Mertens-Walker, J. E. Lisle, A. C. Herington, and S.-A. Stephenson, "Evidence for a dual function of EphB4 as tumor promoter and suppressor regulated by the absence or presence of the ephrin-B2 ligand," International Journal of Cancer, vol. 131, no. 5, pp. E614-E624, 2012.

[53] E. Binda, A. Visioli, F. Giani et al., "The EphA2 Receptor Drives Self-Renewal and Tumorigenicity in Stem-like TumorPropagating Cells from Human Glioblastomas," Cancer Cell, vol. 22, no. 6, pp. 765-780, 2012.
[54] Z. Li, M. H. Theus, and L. Wei, "Role of ERK 1/2 signaling in neuronal differentiation of cultured embryonic stem cells," Development, Growth \& Differentiation, vol. 48, no. 8, pp. 513523, 2006.

[55] M. Wegner, "SOX after SOX: SOXession regulates neurogenesis," Genes \& Development, vol. 25, no. 23, pp. 2423-2428, 2011.

[56] L. H. Pevny and S. K. Nicolis, "Sox2 roles in neural stem cells," The International Journal of Biochemistry \& Cell Biology, vol. 42, no. 3, pp. 421-424, 2010.

[57] H. Miao, N. W. Gale, H. Guo et al., "EphA2 promotes infiltrative invasion of glioma stem cells in vivo through cross-talk with Akt and regulates stem cell properties," Oncogene, vol. 34, no. 5, pp. 558-567, 2015.

[58] J. Wykosky, E. Palma, D. M. Gibo, S. Ringler, C. P. Turner, and W. Debinski, "Soluble monomeric EphrinA1 is released from tumor cells and is a functional ligand for the EphA2 receptor," Oncogene, vol. 27, no. 58, pp. 7260-7273, 2008.

[59] D.-P. Liu, Y. Wang, H. P. Koeffler, and D. Xie, "Ephrin-A1 is a negative regulator in glioma through down-reguation of EphA2 and FAK," International Journal of Oncology, vol. 30, no. 4, pp. 865-871, 2007.

[60] M. Aoki, T. Yamashita, and M. Tohyama, "EphA receptors direct the differentiation of mammalian neural precursor cells through a mitogen-activated protein kinase-dependent pathway," The Journal of Biological Chemistry, vol. 279, no. 31, pp. 32643-32650, 2004.

[61] B. W. Day, B. W. Stringer, F. Al-Ejeh et al., "EphA3 Maintains Tumorigenicity and Is a Therapeutic Target in Glioblastoma Multiforme," Cancer Cell, vol. 23, no. 2, pp. 238-248, 2013.

[62] S. Ferluga, C. M. L. Tomé, D. M. Herpai, R. D’Agostino, and W. Debinski, "Simultaneous targeting of Eph receptors in glioblastoma," Oncotarget, vol. 7, no. 37, pp. 59860-59876, 2016.

[63] J.-J. Li, D.-P. Liu, G.-T. Liu, and D. Xie, "EphrinA5 acts as a tumor suppressor in glioma by negative regulation of epidermal growth factor receptor," Oncogene, vol. 28, no. 15, pp. 1759-1768, 2009.

[64] J. Fukai, H. Yokote, R. Yamanaka, T. Arao, K. Nishio, and T. Itakura, "EphA4 promotes cell proliferation and migration through a novel EphA4-FGFR1 signaling pathway in the human glioma U251 cell line," Molecular Cancer Therapeutics, vol. 7, no. 9, pp. 2768-2778, 2008.

[65] V. Bruce, G. Olivieri, O. Eickelberg, and G. C. Miescher, "Functional activation of EphA5 receptor does not promote cell proliferation in the aberrant EphA5 expressing human glioblastoma U-118 MG cell line," Brain Research, vol. 821, no. 1, pp. 169-176, 1999.

[66] N. Almog, L. Ma, R. Raychowdhury et al., “Transcriptional switch of dormant tumors to fast-growing angiogenic phenotype," Cancer Research, vol. 69, no. 3, pp. 836-844, 2009.

[67] L.-F. Wang, E. Fokas, J. Juricko et al., "Increased expression of EphA7 correlates with adverse outcome in primary and recurrent glioblastoma multiforme patients," BMC Cancer, vol. 8, article no. 79, 2008.

[68] C. Gu, S. Shim, J. Shin et al., "The EphA8 receptor induces sustained MAP kinase activation to promote neurite outgrowth in neuronal cells," Oncogene, vol. 24, no. 26, pp. 4243-4256, 2005.

[69] M. Nakada, J. A. Niska, H. Miyamori et al., "The Phosphorylation of EphB2 Receptor Regulates Migration and Invasion of Human Glioma Cells," Cancer Research, vol. 64, no. 9, pp. 3179$3185,2004$. 
[70] M. Nakada, J. A. Niska, N. L. Tran, W. S. McDonough, and M. E. Berens, "EphB2/R-ras signaling regulates glioma cell adhesion, growth, and invasion," The American Journal of Pathology, vol. 167, no. 2, pp. 565-576, 2005.

[71] S. D. Wang, P. Rath, B. Lal et al., "EphB2 receptor controls proliferation/migration dichotomy of glioblastoma by interacting with focal adhesion kinase," Oncogene, vol. 31, no. 50, pp. 51325143, 2012.

[72] Z. Ying, Y. Li, J. Wu et al., "Loss of miR-204 expression enhances glioma migration and stem cell-like phenotype," Cancer Research, vol. 73, no. 2, pp. 990-999, 2013.

[73] Y. Tu, S. He, J. Fu et al., "Expression of EphrinB2 and EphB4 in glioma tissues correlated to the progression of glioma and the prognosis of glioblastoma patients," Clinical and Translational Oncology, vol. 14, no. 3, pp. 214-220, 2012.

[74] M. Nakada, E. M. Anderson, T. Demuth et al., "The phosphorylation of ephrin-B2 ligand promotes glioma cell migration and invasion," International Journal of Cancer, vol. 126, no. 5, pp. 1155-1165, 2010.

[75] M. Nakada, K. L. Drake, S. Nakada, J. A. Niska, and M. E. Berens, "Ephrin-B3 ligand promotes glioma invasion through activation of Racl," Cancer Research, vol. 66, no. 17, pp. 84928500,2006

[76] Y.-Y. Chuang, N. L. Tran, N. Rusk, M. Nakada, M. E. Berens, and M. Symons, "Role of synaptojanin 2 in glioma cell migration and invasion," Cancer Research, vol. 64, no. 22, pp. 8271-8275, 2004.

[77] S.-y. Wang, L. Yu, G.-q. Ling et al., "Vasculogenic mimicry and its clinical significance in medulloblastoma," Cancer Biology \& Therapy, vol. 13, no. 5, pp. 341-348, 2012.

[78] S. Bhatia, N. A. Baig, O. Timofeeva et al., "Knockdown of ephb1 receptor decreases medulloblastoma cell growth and migration and increases cellular radiosensitization," Oncotarget, vol. 6, no. 11, pp. 8929-8946, 2015.

[79] A. H. Sikkema, W. F. A. Den Dunnen, E. Hulleman et al., "EphB2 activity plays a pivotal role in pediatric medulloblastoma cell adhesion and invasion," Neuro-Oncology, vol. 14, no. 9, pp. 11251135, 2012.

[80] S. Bhatia, K. Hirsch, S. Bukkapatnam et al., "Combined EphB2 receptor knockdown with radiation decreases cell viability and invasion in medulloblastoma," Cancer Cell International, vol. 17, no. 1, article no. 41, 2017.

[81] S. Bhatia, K. Hirsch, N. A. Baig et al., "Effects of altered ephrin-A5 and EphA4/EphA7 expression on tumor growth in a medulloblastoma mouse model," Journal of Hematology \& Oncology, vol. 8, no. 1, article no. 105, 2015.

[82] M. Hynes, W. Ye, K. Wang et al., “The seven-transmembrane receptor Smoothened cell-autonomously induces multiple ventral cell types," Nature Neuroscience, vol. 3, no. 1, pp. 41-46, 2000.

[83] S. D. Karam, R. C. Burrows, C. Logan, S. Koblar, E. B. Pasquale, and M. Bothwell, "Eph receptors and ephrins in the developing chick cerebellum: Relationship to sagittal patterning and granule cell migration," The Journal of Neuroscience, vol. 20, no. 17, pp. 6488-6500, 2000.

[84] W. Hartmann, B. Digon-Söntgerath, A. Koch et al., "Phosphatidylinositol $3^{\prime}$-kinase/AKT signaling is activated in medulloblastoma cell proliferation and is associated with reduced expression of PTEN," Clinical Cancer Research, vol. 12, no. 10, pp. 3019-3027, 2006.

[85] N. McKinney, L. Yuan, H. Zhang et al., "EphrinB1 expression is dysregulated and promotes oncogenic signaling in medulloblastoma," Journal of Neuro-Oncology, vol. 121, no. 1, pp. 109118, 2015.
[86] B. P. Fox, C. J. Tabone, and R. P. Kandpal, "Potential clinical relevance of Eph receptors and ephrin ligands expressed in prostate carcinoma cell lines," Biochemical and Biophysical Research Communications, vol. 342, no. 4, pp. 1263-1272, 2006.

[87] G. Zeng, Z. Hu, M. S. Kinch et al., "High-Level Expression of EphA2 Receptor Tyrosine Kinase in Prostatic Intraepithelial Neoplasia," The American Journal of Pathology, vol. 163, no. 6, pp. 2271-2276, 2003.

[88] J. W. Astin, J. Batson, S. Kadir et al., "Competition amongst Eph receptors regulates contact inhibition of locomotion and invasiveness in prostate cancer cells," Nature Cell Biology, vol. 12, no. 12, pp. 1194-1204, 2010.

[89] A. P. Singh, S. Bafna, K. Chaudhary et al., "Genome-wide expression profiling reveals transcriptomic variation and perturbed gene networks in androgen-dependent and androgenindependent prostate cancer cells," Cancer Letters, vol. 259, no. 1, pp. 28-38, 2008.

[90] J. Zhou, W. Huang, R. Tao et al., "Inactivation of AMPK alters gene expression and promotes growth of prostate cancer cells," Oncogene, vol. 28, no. 18, pp. 1993-2002, 2009.

[91] S. Ashida, H. Nakagawa, T. Katagiri et al., "Molecular features of the transition from prostatic intraepithelial neoplasia (PIN) to prostate cancer: genome-wide gene-expression profiles of prostate cancers and PINs," Cancer Research, vol. 64, no. 17, pp. 5963-5972, 2004.

[92] M. Soler, F. Mancini, Ó. Meca-Cortés et al., "HER3 is required for the maintenance of neuregulin-dependent and independent attributes of malignant progression in prostate cancer cells," International Journal of Cancer, vol. 125, no. 11, pp. 2565-2575, 2009.

[93] P. Huusko, D. Ponciano-Jackson, M. Wolf et al., "Nonsensemediated decay microarray analysis identifies mutations of EPHB2 in human prostate cancer," Nature Genetics, vol. 36, no. 9, pp. 979-983, 2004.

[94] S. E. T. Larkin, S. Holmes, I. A. Cree et al., "Identification of markers of prostate cancer progression using candidate gene expression," British Journal of Cancer, vol. 106, no. 1, pp. 157-165, 2012.

[95] D. B. Martin, D. R. Gifford, M. E. Wright et al., "Quantitative Proteomic Analysis of Proteins Released by Neoplastic Prostate Epithelium," Cancer Research, vol. 64, no. 1, pp. 347-355, 2004.

[96] M. Kälin, I. Cima, R. Schiess et al., "Novel prognostic markers in the serum of patients with castration-resistant prostate cancer derived from quantitative analysis of the pten conditional knockout mouse proteome," European Urology, vol. 60, no. 6, pp. 1235-1243, 2011.

[97] N. I. Herath, M. D. Spanevello, J. D. Doecke, F. M. Smith, C. Pouponnot, and A. W. Boyd, "Complex expression patterns of Eph receptor tyrosine kinases and their ephrin ligands in colorectal carcinogenesis," European Journal of Cancer, vol. 48, no. 5, pp. 753-762, 2012.

[98] N. I. Herath, J. Doecke, M. D. Spanevello, B. A. Leggett, and A. W. Boyd, "Epigenetic silencing of EphA1 expression in colorectal cancer is correlated with poor survival," British Journal of Cancer, vol. 100, no. 7, pp. 1095-1102, 2009.

[99] Y. Dong, J. Wang, Z. Sheng et al., "Downregulation of EphA1 in colorectal carcinomas correlates with invasion and metastasis," Modern Pathology, vol. 22, no. 1, pp. 151-160, 2009.

[100] B. O. Wu, W. G. Jiang, D. Zhou, and Y.-X. Cui, "Knockdown of ephal by crispr/cas9 promotes adhesion and motility of hrt18 colorectal carcinoma cells," Anticancer Reseach, vol. 36, no. 3, pp. 1211-1220, 2016. 
[101] P. D. Dunne, S. Dasgupta, J. K. Blayney et al., "EphA2 expression is a key driver of migration and invasion and a poor prognostic marker in colorectal cancer," Clinical Cancer Research, vol. 22, no. 1, pp. 230-242, 2016.

[102] G. Zhang, J. Brady, W.-C. Liang, Y. Wu, M. Henkemeyer, and M. Yan, "EphB4 forward signalling regulates lymphatic valve development," Nature Communications, vol. 6, article 6625, 2015.

[103] J. Wang, H. Kataoka, M. Suzuki et al., "Downregulation of EphA7 by hypermethylation in colorectal cancer," Oncogene, vol. 24, no. 36, pp. 5637-5647, 2005.

[104] S. R. Kumar, J. S. Scehnet, E. J. Ley et al., "Preferential induction of EphB4 over EphB2 and its implication in colorectal cancer progression," Cancer Research, vol. 69, no. 9, pp. 3736-3745, 2009.

[105] N. I. Herath and A. W. Boyd, "The role of Eph receptors and ephrin ligands in colorectal cancer," International Journal of Cancer, vol. 126, no. 9, pp. 2003-2011, 2010.

[106] S.-T. Chiu, K.-J. Chang, C.-H. Ting, H.-C. Shen, H. Li, and F.-J. Hsieh, "Over-expression of EphB3 enhances cell-cell contacts and suppresses tumor growth in HT-29 human colon cancer cells," Carcinogenesis, vol. 30, no. 9, pp. 1475-1486, 2009.

[107] C. Cortina, S. Palomo-Ponce, M. Iglesias et al., "EphB-ephrinB interactions suppress colorectal cancer progression by compartmentalizing tumor cells," Nature Genetics, vol. 39, no. 11, pp. 1376-1383, 2007.

[108] J. Lv, Q. Xia, J. Wang, Q. Shen, J. Zhang, and X. Zhou, "EphB4 promotes the proliferation, invasion, and angiogenesis of human colorectal cancer," Experimental and Molecular Pathology, vol. 100, no. 3, pp. 402-408, 2016.

[109] M. A. Stammes, H. A. J. M. Prevoo, M. C. Ter Horst et al., "Evaluation of EphA2 and EphB4 as targets for image-guided colorectal cancer surgery," International Journal of Molecular Sciences, vol. 18, no. 2, article no. 307, 2017.

[110] L. Peng, P. Tu, X. Wang, S. Shi, X. Zhou, and J. Wang, "Loss of EphB6 protein expression in human colorectal cancer correlates with poor prognosis," Journal of Molecular Histology, vol. 45, no. 5, pp. 555-563, 2014.

[111] S. Mateo-Lozano, S. Bazzocco, P. Rodrigues et al., "Loss of the EPH receptor B6 contributes to colorectal cancer metastasis," Scientific Reports, vol. 7, Article ID 43702, 2017.

[112] J. K. Chilton, "Molecular mechanisms of axon guidance," Developmental Biology, vol. 292, no. 1, pp. 13-24, 2006.

[113] N. J. Xu and M. Henkemeyer, "Ephrin reverse signaling in axon guidance and synaptogenesis," Seminars in Cell \& Developmental Biology, vol. 23, no. 1, pp. 58-64, 2012.

[114] E. Herrera, L. Brown, J. Aruga et al., "Zic2 patterns binocular vision by specifying the uncrossed retinal projection," Cell, vol. 114, no. 5, pp. 545-557, 2003.

[115] L. Erskine, S. Reijntjes, T. Pratt et al., "VEGF Signaling through Neuropilin 1 Guides Commissural Axon Crossing at the Optic Chiasm," Neuron, vol. 70, no. 5, pp. 951-965, 2011.

[116] S. E. Williams, M. Grumet, D. R. Colman, M. Henkemeyer, C. A. Mason, and T. Sakurai, "A Role for Nr-CAM in the Patterning of Binocular Visual Pathways," Neuron, vol. 50, no. 4, pp. 535-547, 2006.

[117] T. Kuwajima, Y. Yoshida, N. Takegahara et al., "Optic Chiasm Presentation of Semaphorin6D in the Context of Plexin-A1 and Nr-CAM Promotes Retinal Axon Midline Crossing," Neuron, vol. 74, no. 4, pp. 676-690, 2012.
[118] S. E. Williams, F. Mann, L. Erskine et al., "Ephrin-B2 and EphB1 mediate retinal axon divergence at the optic chiasm," Neuron, vol. 39, no. 6, pp. 919-935, 2003.

[119] A. Escalante, B. Murillo, C. Morenilla-Palao, A. Klar, and E. Herrera, "Zic2-dependent axon midline avoidance controls the formation of major ipsilateral tracts in the CNS," Neuron, vol. 80, no. 6, pp. 1392-1406, 2013.

[120] J. C. Conover, F. Doetsch, J.-M. Garcia-Verdugo, N. W. Gale, G. D. Yancopoulos, and A. Alvarez-Buylla, "Disruption of Eph/ephrin signaling affects migration and proliferation in the adult subventricular zone," Nature Neuroscience, vol. 3, no. 11, pp. 1091-1097, 2000.

[121] Y. Hara, T. Nomura, K. Yoshizaki, J. Frisén, and N. Osumi, "Impaired hippocampal neurogenesis and vascular formation in ephrin-A5-deficient mice," Stem Cells, vol. 28, no. 5, pp. 974983, 2010.

[122] J. Holmberg, A. Armulik, K.-A. Senti et al., "Ephrin-A2 reverse signaling negatively regulates neural progenitor proliferation and neurogenesis," Genes \& Development, vol. 19, no. 4, pp. 462471, 2005.

[123] J. Ricard, J. Salinas, L. Garcia, and D. J. Liebl, "EphrinB3 regulates cell proliferation and survival in adult neurogenesis," Molecular and Cellular Neuroscience, vol. 31, no. 4, pp. 713-722, 2006.

[124] K. del Valle, M. H. Theus, J. R. Bethea, D. J. Liebl, and J. Ricard, "Neural progenitors proliferation is inhibited by EphB3 in the developing subventricular zone," International Journal of Developmental Neuroscience, vol. 29, no. 1, pp. 9-14, 2011.

[125] J.-W. Jiao, D. A. Feldheim, and D. F. Chen, "Ephrins as negative regulators of adult neurogenesis in diverse regions of the central nervous system," Proceedings of the National Acadamy of Sciences of the United States of America, vol. 105, no. 25, pp. 8778-8783, 2008.

[126] H. U. Wang, Z.-F. Chen, and D. J. Anderson, "Molecular distinction and angiogenic interaction between embryonic arteries and veins revealed by ephrin-B2 and its receptor Eph-B4," Cell, vol. 93, no. 5, pp. 741-753, 1998.

[127] R. H. Adams, G. A. Wilkinson, C. Weiss et al., "Roles of ephrinB ligands and EphB receptors in cardiovascular development: Demarcation of arterial/venous domains, vascular morphogenesis, and sprouting angiogenesis," Genes \& Development, vol. 13, no. 3, pp. 295-306, 1999.

[128] S. P. Herbert, J. Huisken, T. N. Kim et al., "Arterial-venous segregation by selective cell sprouting: an alternative mode of blood vessel formation," Science, vol. 326, no. 5950, pp. 294-298, 2009.

[129] Y. Wang, M. Nakayama, M. E. Pitulescu et al., "Ephrin-B2 controls VEGF-induced angiogenesis and lymphangiogenesis," Nature, vol. 465, no. 7297, pp. 483-486, 2010.

[130] M. Nakayama, A. Nakayama, M. van Lessen et al., "Spatial regulation of VEGF receptor endocytosis in angiogenesis," Nature Cell Biology, vol. 15, no. 3, pp. 249-260, 2013.

[131] K.-W. Kim and J.-H. Song, "Emerging roles of lymphatic vasculature in immunity," Immune Network, vol. 17, no. 1, pp. 68-76, 2017.

[132] E. Bazigou and T. Makinen, "Flow control in our vessels: Vascular valves make sure there is no way back," Cellular and Molecular Life Sciences, vol. 70, no. 6, pp. 1055-1066, 2013.

[133] T. Mäkinen, R. H. Adams, J. Bailey et al., "PDZ interaction site in ephrinB2 is required for the remodeling of lymphatic vasculature," Genes \& Development, vol. 19, no. 3, pp. 397-410, 2005. 
[134] S. S. Foo, C. J. Turner, S. Adams et al., "Ephrin-B2 controls cell motility and adhesion during blood-vessel-wall assembly," Cell, vol. 124, no. 1, pp. 161-173, 2006.

[135] A. Nakayama, M. Nakayama, C. J. Turner, S. Hoing, J. J. Lepore, and R. H. Adams, "Ephrin-B2 controls PDGFR internalization and signaling," Genes \& Development, vol. 27, no. 23, pp. 25762589, 2013.

[136] M. Lackmann and A. W. Boyd, "Eph, a protein family coming of age: more confusion, insight, or complexity?" Science Signaling, vol. 1, no. 15, article re2, 2008.

[137] C. Baldwin, Z. W. Chen, A. Bedirian et al., "Upregulation of EphA2 during in vivo and in vitro renal ischemia-reperfusion injury: Role of Src kinases," American Journal of PhysiologyRenal Physiology, vol. 291, no. 5, pp. F960-F971, 2006.

[138] M. M. Vihanto, J. Plock, D. Erni, B. M. Frey, F. J. Frey, and U. Huynh-Do, "Hypoxia up-regulates expression of Eph receptors and ephrins in mouse skin," The FASEB Journal, vol. 19, no. 12, pp. 1689-1691, 2005.

[139] X. Liu, E. Hawkes, T. Ishimaru, T. Tran, and D. W. Sretavan, "EphB3: An endogenous mediator of adult axonal plasticity and regrowth after CNS injury," The Journal of Neuroscience, vol. 26, no. 12, pp. 3087-3101, 2006.

[140] M. G. Coulthard, M. Morgan, T. M. Woodruff et al., "Eph/ephrin signaling in injury and inflammation," The American Journal of Pathology, vol. 181, no. 5, pp. 1493-1503, 2012.

[141] Y. Goldshmit, M. P. Galea, G. Wise, P. F. Bartlett, and A. M. Turnley, "Axonal regeneration and lack of astrocytic gliosis in EphA4-deficient mice," The Journal of Neuroscience, vol. 24, no. 45, pp. 10064-10073, 2004.

[142] Y. Goldshmit and J. Bourne, "Upregulation of epha4 on astrocytes potentially mediates astrocytic gliosis after cortical lesion in the marmoset monkey," Journal of Neurotrauma, vol. 27, no. 7, pp. 1321-1332, 2010.

[143] J.-P. Himanen and D. B. Nikolov, "Eph signaling: a structural view," Trends in Neurosciences, vol. 26, no. 1, pp. 46-51, 2003.

[144] J. P. Himanen, L. Yermekbayeva, P. W. Janes et al., "Architecture of Eph receptor clusters," Proceedings of the National Acadamy of Sciences of the United States of America, vol. 107, no. 24, pp. 10860-10865, 2010.

[145] A. Schaupp, O. Sabet, I. Dudanova, M. Ponserre, P. Bastiaens, and R. Klein, "The composition of EphB2 clusters determines the strength in the cellular repulsion response," The Journal of Cell Biology, vol. 204, no. 3, pp. 409-422, 2014.

[146] M. Zimmer, A. Palmer, J. Köhler, and R. Klein, “EphB-ephrinB bi-directional endocytosis terminates adhesion allowing contact mediated repulsion," Nature Cell Biology, vol. 5, no. 10, pp. 869-878, 2003.

[147] D. J. Marston, S. Dickinson, and C. D. Nobes, "Rac-dependent trans-endocytosis of ephrinBs regulates Eph-ephrin contact repulsion," Nature Cell Biology, vol. 5, no. 10, pp. 879-888, 2003.

[148] J. Egea and R. Klein, "Bidirectional Eph-ephrin signaling during axon guidance," Trends in Cell Biology, vol. 17, no. 5, pp. 230-238, 2007.

[149] C. J. Vearing and M. Lackmann, "Eph receptor signalling; dimerisation just isn't enough," Growth Factors, vol. 23, no. 1, pp. 67-76, 2005.

[150] Y. Yin, Y. Yamashita, H. Noda, T. Okafuji, M. J. Go, and H. Tanaka, "EphA receptor tyrosine kinases interact with coexpressed ephrin-A ligands in cis," Neuroscience Research, vol. 48, no. 3, pp. 285-296, 2004.
[151] R. F. Carvalho, M. Beutler, K. J. M. Marler et al., "Silencing of EphA3 through a cis interaction with ephrinA5," Nature Neuroscience, vol. 9, no. 3, pp. 322-330, 2006.

[152] M. S. Kalo and E. B. Pasquale, "Multiple in vivo tyrosine phosphorylation sites in EphB receptors," Biochemistry, vol. 38, no. 43, pp. 14396-14408, 1999.

[153] L. Van Aelst and C. D'Souza-Schorey, "Rho GTPases and signaling networks," Genes \& Development, vol. 11, no. 18, pp. 2295-2322, 1997.

[154] A. Palmer, M. Zimmer, K. S. Erdmann et al., "EphrinB phosphorylation and reverse signaling: Regulation by Src kinases and PTP-BL phosphatase," Molecular Cell, vol. 9, no. 4, pp. 725-737, 2002.

[155] C. A. Cowan and M. Henkemeyer, "The SH2/SH3 adaptor Grb4 transduces B-ephrin reverse signals," Nature, vol. 413, no. 6852, pp. 174-179, 2001.

[156] K. Kullander and R. Klein, "Mechanisms and functions of Eph and ephrin signalling," Nature Reviews Molecular Cell Biology, vol. 3, no. 7, pp. 475-486, 2002.

[157] R. L. Siegel, K. D. Miller, and A. Jemal, "Cancer statistics, 2016," CA: A Cancer Journal for Clinicians, vol. 66, no. 1, pp. 7-30, 2016.

[158] G. D'Addario and E. Felip, "Non-small-cell lung cancer: ESMO Clinical Recommendations for diagnosis, treatment and followup," Annals of Oncology, vol. 20, no. 4, pp. iv68-iv70, 2009.

[159] T. D. Bartley, R. W. Hunt, A. A. Welcher et al., "B61 is a ligand for the ECK receptor protein-tyrosine kinase," Nature, vol. 368, no. 6471, pp. 558-560, 1994.

[160] A. K. Rud, M. Lund-Iversen, G. Berge et al., "Expression of S100A4, ephrin-A1 and osteopontin in non-small cell lung cancer," BMC Cancer, vol. 12, article no. 333, 2012.

[161] M. Ishikawa, R. Miyahara, M. Sonobe et al., "Higher expression of EphA2 and ephrin-A1 is related to favorable clinicopathological features in pathological stage I non-small cell lung carcinoma," Lung Cancer, vol. 76, no. 3, pp. 431-438, 2012.

[162] J. Peng, Q. Wang, H. Liu, M. Ye, X. Wu, and L. Guo, "EPHA3 regulates the multidrug resistance of small cell lung cancer via the PI3K/BMX/STAT3 signaling pathway," Tumor Biology, vol. 37, no. 9, pp. 11959-11971, 2016.

[163] C. Müller-Tidow, S. Diederichs, E. Bulk et al., "Identification of metastasis-associated receptor tyrosine kinases in non-small cell lung cancer," Cancer Research, vol. 65, no. 5, pp. 1778-1782, 2005.

[164] E. Bulk, J. Yu, A. Hascher et al., "Mutations of the EPHB6 Receptor Tyrosine Kinase Induce a Pro-Metastatic Phenotype in Non-Small Cell Lung Cancer," PLoS ONE, vol. 7, no. 12, Article ID e44591, 2012.

[165] K. Carles-Kinch, K. E. Kilpatrick, J. C. Stewart, and M. S. Kinch, "Antibody targeting of the EphA2 tyrosine kinase inhibits malignant cell behavior," Cancer Research, vol. 62, no. 10, pp. 2840-2847, 2002.

[166] D. P. Zelinski, N. D. Zantek, J. C. Stewart, A. R. Irizarry, and M. S. Kinch, "EphA2 overexpression causes tumorigenesis of mammary epithelial cells," Cancer Research, vol. 61, no. 5, pp. 2301-2306, 2001.

[167] W. B. Fang, D. M. Brantley-Sieders, M. A. Parker, A. D. Reith, and J. Chen, "A kinase-dependent role for EphA2 receptor in promoting tumor growth and metastasis," Oncogene, vol. 24, no. 53, pp. 7859-7868, 2005.

[168] M. Lu, K. D. Miller, Y. Gokmen-Polar, M.-H. Jeng, and M. S. Kinch, "EphA2 overexpression decreases estrogen dependence and tamoxifen sensitivity," Cancer Research, vol. 63, no. 12, pp. 3425-3429, 2003. 
[169] J. Kurebayashi, M. Nukatsuka, H. Sonoo, J. Uchida, and M. Kiniwa, "Preclinical rationale for combined use of endocrine therapy and 5-fluorouracil but neither doxorubicin nor paclitaxel in the treatment of endocrine-responsive breast cancer," Cancer Chemotherapy and Pharmacology, vol. 65, no. 2, pp. 219225, 2010.

[170] G. Berclaz, B. Flütsch, H. J. Altermatt et al., "Loss of EphB4 receptor tyrosine kinase protein expression during carcinogenesis of the human breast.", Oncology Reports, vol. 9, no. 5, pp. 985-989, 2002.

[171] Q. Wu, Z. Suo, B. Risberg, M. G. Karlsson, K. Villman, and J. M. Nesland, "Expression of Ephb2 and Ephb4 in breast carcinoma," Pathology \& Oncology Research, vol. 10, no. 1, pp. 26-33, 2004.

[172] K. K. Murai and E. B. Pasquale, "'Eph'ective signaling: forward, reverse and crosstalk," Journal of Cell Science, vol. 116, no. 14, pp. 2823-2832, 2003.

[173] B. P. Fox and R. P. Kandpal, "Invasiveness of breast carcinoma cells and transcript profile: Eph receptors and ephrin ligands as molecular markers of potential diagnostic and prognostic application," Biochemical and Biophysical Research Communications, vol. 318, no. 4, pp. 882-892, 2004.

[174] B. P. Fox and R. P. Kandpal, "DNA-based assay for EPHB6 expression in breast carcinoma cells as a potential diagnostic test for detecting tumor cells in circulation," Cancer Genomics \& Proteomics, vol. 7, no. 1, pp. 9-16, 2010.

[175] B. P. Fox and R. P. Kandpal, "EphB6 receptor significantly alters invasiveness and other phenotypic characteristics of human breast carcinoma cells," Oncogene, vol. 28, no. 14, pp. 1706-1713, 2009.

[176] Q. T. Ostrom, L. Bauchet, F. G. Davis et al., “The epidemiology of glioma in adults: A state of the science review," Neuro-Oncology, vol. 16, no. 7, pp. 896-913, 2014.

[177] D. N. Louis, H. Ohgaki, O. D. Wiestler et al., "The 2007 WHO classification of tumours of the central nervous system," Acta Neuropathologica, vol. 114, no. 2, pp. 97-109, 2007.

[178] P. A. Northcott, D. T. W. Jones, M. Kool et al., "Medulloblastomics: the end of the beginning," Nature Reviews Cancer, vol. 12, no. 12, pp. 818-834, 2012.

[179] P. Fiorilli, D. Partridge, I. Staniszewska et al., "Integrins mediate adhesion of medulloblastoma cells to tenascin and activate pathways associated with survival and proliferation," Laboratory Investigation, vol. 88, no. 11, pp. 1143-1156, 2008.

[180] J. Wykosky, D. M. Gibo, C. Stanton, and W. Debinski, "EphA2 as a novel molecular marker and target in glioblastoma multiforme," Molecular Cancer Research, vol. 3, no. 10, pp. 541-551, 2005.

[181] X. Li, Y. Wang, Y. Wang et al., "Expression of EphA2 in human astrocytic tumors: correlation with pathologic grade, proliferation and apoptosis," Tumor Biology, vol. 28, no. 3, pp. 165-172, 2007.

[182] L-F. Wang, E. Fokas, M. Bieker et al., "Increased expression of EphA2 correlates with adverse outcome in primary and recurrent glioblastoma multiforme patients," Oncol Rep, vol. 19, no. 1, pp. 151-156, 2008.

[183] B. W. Day, B. W. Stringer, and A. W. Boyd, "Eph receptors as therapeutic targets in glioblastoma," British Journal of Cancer, vol. 111, no. 7, pp. 1255-1261, 2014.

[184] R. Erber, U. Eichelsbacher, V. Powajbo et al., "EphB4 controls blood vascular morphogenesis during postnatal angiogenesis," EMBO Journal, vol. 25, no. 3, pp. 628-641, 2006.
[185] J.-L. Li, R. C. A. Sainson, C. E. Oon et al., "DLL4-Notch signaling mediates tumor resistance to anti-VEGF therapy in vivo," Cancer Research, vol. 71, no. 18, pp. 6073-6083, 2011.

[186] S. Sawamiphak, S. Seidel, C. L. Essmann et al., "Ephrin-B2 regulates VEGFR2 function in developmental and tumour angiogenesis," Nature, vol. 465, no. 7297, pp. 487-491, 2010.

[187] N.-Y. Yang, C. Fernandez, M. Richter et al., "Crosstalk of the EphA2 receptor with a serine/threonine phosphatase suppresses the Akt-mTORC1 pathway in cancer cells," Cellular Signalling, vol. 23, no. 1, pp. 201-212, 2011.

[188] J.-P. Lin, B.-C. Pan, B. Li, Y. Li, X.-Y. Tian, and Z. Li, "DJ1 is activated in medulloblastoma and is associated with cell proliferation and differentiation," World Journal of Surgical Oncology, vol. 12, no. 1, article no. 373, 2014.

[189] J. Romero Otero, B. Garcia Gomez, F. Campos Juanatey, and K. A. Touijer, "Prostate cancer biomarkers: an update," Urologic Oncology: Seminars and Original Investigations, vol. 32, no. 3, pp. 252-260, 2014.

[190] K. C. Cary and M. R. Cooperberg, "Biomarkers in prostate cancer surveillance and screening: Past, present, and future," Therapeutic Advances in Urology, vol. 5, no. 6, pp. 318-329, 2013.

[191] J. Walker-Daniels, K. Coffman, M. Azimi et al., "Overexpression of the EphA2 tyrosine kinase in prostate cancer," The Prostate, vol. 41, no. 4, pp. 275-280, 1999.

[192] H. Miao, B.-R. Wei, D. M. Peehl et al., "Activation of EphA receptor tyrosine kinase inhibits the Ras/MAPK pathway," Nature Cell Biology, vol. 3, no. 5, pp. 527-530, 2001.

[193] H. Miao, E. Burnett, M. Kinch, E. Simon, and B. Wang, "Activation of EphA2 kinase suppresses integrin function and causes focal-adhesion-kinase dephosphorylation," Nature Cell Biology, vol. 2, no. 2, pp. 62-69, 2000.

[194] L. Salmena, A. Carracedo, and P. P. Pandolfi, "Tenets of PTEN tumor suppression," Cell, vol. 133, no. 3, pp. 403-414, 2008.

[195] M. L. Taddei, M. Parri, A. Angelucci et al., "Kinase-dependent and -independent roles of EphA2 in the regulation of prostate cancer invasion and metastasis," The American Journal of Pathology, vol. 174, no. 4, pp. 1492-1503, 2009.

[196] M. L. Taddei, M. Parri, A. Angelucci et al., "EphA2 induces metastatic growth regulating amoeboid motility and clonogenic potential in prostate carcinoma cells," Molecular Cancer Research, vol. 9, no. 2, pp. 149-160, 2011.

[197] A. E. Ross, L. Marchionni, M. Vuica-Ross et al., "Gene expression pathways of high grade localized prostate cancer," The Prostate, vol. 71, no. 14, pp. 1568-1578, 2011.

[198] K. Jennbacken, H. Gustavsson, T. Tešan et al., "The prostatic environment suppresses growth of androgen-independent prostate cancer xenografts: An effect influenced by testosterone," The Prostate, vol. 69, no. 11, pp. 1164-1175, 2009.

[199] M. Guan, C. Xu, F. Zhang, and C. Ye, "Aberrant methylation of EphA7 in human prostate cancer and its relation to clinicopathologic features," International Journal of Cancer, vol. 124, no. 1, pp. 88-94, 2009.

[200] A. J. Oudes, J. C. Roach, L. S. Walashek et al., "Application of affymetrix array and massively parallel signature sequencing for identification of genes involved in prostate cancer progression," BMC Cancer, vol. 5, article no. 86, 2005.

[201] S. Tao, Z. Wang, J. Feng et al., "A genome-wide search for loci interacting with known prostate cancer risk-associated genetic variants," Carcinogenesis, vol. 33, no. 3, pp. 598-603, 2012.

[202] R. A. Kittles, A. B. Boffoe-Bonnie, T. Y. Moses et al., "A common nonsense mutation in EphB2 is associated with prostate cancer 
risk in African American men with a positive family history," Journal of Medical Genetics, vol. 43, no. 6, pp. 507-511, 2006.

[203] A. Jemal, M. M. Center, C. DeSantis, and E. M. Ward, "Global patterns of cancer incidence and mortality rates and trends," Cancer Epidemiology, Biomarkers \& Prevention, vol. 19, no. 8, pp. 1893-1907, 2010.

[204] H. Chaib, E. K. Cockrell, M. A. Rubin, and J. A. Macoska, "Profiling and verification of gene expression patterns in normal and malignant human prostate tissues by cDNA microarray analysis," Neoplasia, vol. 3, no. 1, pp. 43-52, 2001.

[205] Y.-C. Lee, J. R. Perren, E. L. Douglas et al., "Investigation of the expression of the EphB4 receptor tyrosine kinase in prostate carcinoma," BMC Cancer, vol. 5, article no. 119, 2005.

[206] G. Xia, S. R. Kumar, R. Masood et al., "EphB4 expression and biological significance in prostate cancer," Cancer Research, vol. 65, no. 11, pp. 4623-4632, 2005.

[207] M. Arnold, M. S. Sierra, M. Laversanne, I. Soerjomataram, A. Jemal, and F. Bray, "Global patterns and trends in colorectal cancer incidence and mortality," Gut, 2016.

[208] F. Kastrinos and S. Syngal, "Inherited colorectal cancer syndromes," Cancer Journal, vol. 17, no. 6, pp. 405-415, 2011.

[209] E. Batlle, J. T. Henderson, H. Beghtel et al., “ $\beta$-catenin and TCF mediate cell positioning in the intestinal epithelium by controlling the expression of EphB/EphrinB," Cell, vol. 111, no. 2, pp. 251-263, 2002.

[210] E. Batlle, J. Bacani, H. Begthel et al., "EphB receptor activity suppresses colorectal cancer progression," Nature, vol. 435, no. 7045, pp. 1126-1130, 2005.

[211] C. Hafner, G. Schmitz, S. Meyer et al., "Differential gene expression of Eph receptors and ephrins in benign human tissue and cancers," Clinical Chemistry, vol. 50, no. 3, pp. 490-490, 2004.

[212] D. L. Guo, J. Zhang, S. T. Yuen et al., "Reduced expression of EphB2 that parallels invasion and metastasis in colorectal tumours," Carcinogenesis, vol. 27, no. 3, pp. 454-464, 2006.

[213] A. Lugli, H. Spichtin, R. Maurer et al., "EphB2 expression across 138 human tumor types in a tissue microarray: High levels of expression in gastrointestinal cancers," Clinical Cancer Research, vol. 11, no. 18, pp. 6450-6458, 2005.

[214] A. M. Jubb, F. Zhong, S. Bheddah et al., "EphB2 is a prognostic factor in colorectal cancer," Clinical Cancer Research, vol. 11, no. 14, pp. 5181-5187, 2005.

[215] S.-A. Stephenson, S. Slomka, E. L. Douglas, P. J. Hewett, and J. E. Hardingham, "Receptor protein tyrosine kinase EphB4 is upregulated in colon cancer," BMC Molecular Biology, vol. 2, article no. 15, 2001.

[216] G. Ciasca, M. Papi, E. Minelli, V. Palmieri, and M. De Spirito, "Changes in cellular mechanical properties during onset or progression of colorectal cancer," World Journal of Gastroenterology, vol. 22, no. 32, pp. 7203-7214, 2016.

[217] T.-J. Kao and A. Kania, "Ephrin-Mediated cis-Attenuation of Eph Receptor Signaling Is Essential for Spinal Motor Axon Guidance," Neuron, vol. 71, no. 1, pp. 76-91, 2011.

[218] E. M. Lisabeth, C. Fernandez, and E. B. Pasquale, "Cancer somatic mutations disrupt functions of the EphA3 receptor tyrosine kinase through multiple mechanisms," Biochemistry, vol. 51, no. 7, pp. 1464-1475, 2012.

[219] M. A. Huber, N. Kraut, and H. Beug, "Molecular requirements for epithelial-mesenchymal transition during tumor progression," Current Opinion in Cell Biology, vol. 17, no. 5, pp. 548-558, 2005.
[220] H. Maio and B. Wang, "EphA receptor signaling - complexity and emerging themes," Seminarsin Cell \& Developmental Biology, vol. 23, no. 1, pp. 16-25, 2012.

[221] S. K. Singh, I. D. Clarke, T. Hide, and P. B. Dirks, "Cancer stem cells in nervous system tumors," Oncogene, vol. 23, no. 43, pp. 7267-7273, 2004.

[222] A. Kreso and J. Dick, "Evolution of the cancer stem cell model," Cell Stem Cell, vol. 14, no. 3, pp. 275-291, 2014.

[223] D. S. Chen and I. Mellman, "Oncology meets immunology: the cancer-immunity cycle," Immunity, vol. 39, no. 1, pp. 1-10, 2013.

[224] G. Yu, H. Luo, Y. Wu, and J. Wu, "Ephrin B2 induces T cell costimulation," The Journal of Immunology, vol. 171, no. 1, pp. 106-114, 2003.

[225] G. Yu, H. Luo, Y. Wu, and J. Wu, "Mouse EphrinB3 Augments T-cell Signaling and Responses to T-cell Receptor Ligation," The Journal of Biological Chemistry, vol. 278, no. 47, pp. 4720947216, 2003.

[226] G. Yu, H. Luo, Y. Wu, and J. Wu, "EphrinB1 is essential in Tcell-T-cell co-operation during T-cell activation," The Journal of Biological Chemistry, vol. 279, no. 53, pp. 55531-55539, 2004.

[227] H. Luo, G. Yu, Y. Wu, and J. Wu, "EphB6 crosslinking results in costimulation of T cells," The Journal of Clinical Investigation, vol. 110, no. 8, pp. 1141-1150, 2002.

[228] H. Luo, G. Yu, J. Tremblay, and J. Wu, "EphB6-null mutation results in compromised T cell function," The Journal of Clinical Investigation, vol. 114, no. 12, pp. 1762-1773, 2004.

[229] C. E. Chee, S. Krishnamurthi, C. J. Nock et al., "Phase II study of dasatinib (BMS-354825) in patients with metastatic adenocarcinoma of the pancreas," The Oncologist, vol. 18, no. 10, pp. 1091-1092, 2013.

[230] M. J. Kelley, G. Jha, D. Shoemaker et al., "Phase II Study of Dasatinib in Previously Treated Patients with Advanced NonSmall Cell Lung Cancer," Cancer Investigation, vol. 35, no. 1, pp. 32-35, 2017.

[231] S. M. Schuetze, J. K. Wathen, D. R. Lucas et al., "SARC009: Phase 2 study of dasatinib in patients with previously treated, highgrade, advanced sarcoma," Cancer, vol. 122, no. 6, pp. 868-874, 2016.

[232] Y. Ishida, K. Murai, K. Yamaguchi et al., "Pharmacokinetics and pharmacodynamics of dasatinib in the chronic phase of newly diagnosed chronic myeloid leukemia," European Journal of Clinical Pharmacology, vol. 72, no. 2, pp. 185-193, 2016.

[233] C. M. Annunziata, E. C. Kohn, P. Lorusso et al., "Phase 1, openlabel study of MEDI-547 in patients with relapsed or refractory solid tumors," Investigational New Drugs, vol. 31, no. 1, pp. 77-84, 2013.

[234] S. Charmsaz and A. W. Boyd, "Eph receptors as oncotargets," Oncotarget, vol. 8, no. 47, pp. 81727-81728, 2017.

[235] S. Charmsaz, A. M. Scott, and A. W. Boyd, "Targeted therapies in hematological malignancies using therapeutic monoclonal antibodies against Eph family receptors," Experimental Hematology, vol. 54, Supplement C, pp. 31-39, 2017.

[236] J. J. Munoz, L. M. Alonso-C, R. Sacedon et al., "Expression and function of the EphA receptors and their ligand ephrin in the rat thymus," Journal of Immunology, vol. 169, no. 1, p. 177, 2002.

[237] M. Shimoyama, H. Matsuoka, A. Nagata et al., "Developmental expression of EphB6 in the thymus: Lessons from EphB6 knockout mice," Biochemical and Biophysical Research Communications, vol. 298, no. 1, pp. 87-94, 2002.

[238] G. Yu, J. Mao, Y. Wu, H. Luo, and J. Wu, "Ephrin-B1 is critical in T-cell development," The Journal of Biological Chemistry, vol. 281, no. 15, pp. 10222-10229, 2006. 
[239] M. G. Coulthard, J. D. Lickliter, N. Subanesan et al., "Characterization of the EphA1 receptor tyrosine kinase: Expression in epithelial tissues," Growth Factors, vol. 18, no. 4, pp. 303-317, 2001.

[240] N. I. Herath, M. D. Spanevello, J. D. Doecke, F. M. Smith, C. Pouponnot, and D. W. Boywd, "Complex expression patterns of Eph receptor tyrosine kinase and their ephrin ligands in colorectal carcinogenesis," European Journal of Cancer, vol. 48, no. 5, pp. 753-762, 2012.

[241] L. Mathot, S. Kundu, V. Ljungström et al., "Somatic ephrin receptor mutations are associated with metastasis in primary colorectal cancer," Cancer Research, vol. 77, no. 7, pp. 1730-1740, 2017.

[242] L. Morsut, K. T. Roybal, X. Xiong et al., "Engineering Customized Cell Sensing and Response Behaviors Using Synthetic Notch Receptors," Cell, vol. 164, no. 4, pp. 780-791, 2016.

[243] B. Beck and C. Blanpain, "Unravelling cancer stem cell potential," Nature Reviews Cancer, vol. 13, no. 10, pp. 727-738, 2013.

[244] C. Hogan, S. Dupré-Crochet, M. Norman et al., "Characterization of the interface between normal and transformed epithelial cells," Nature Cell Biology, vol. 11, no. 4, pp. 460-467, 2009.

[245] S. Porazinski, J. de Navascués, Y. Yako et al., "EphA2 Drives the Segregation of Ras-Transformed Epithelial Cells from Normal Neighbors," Current Biology, vol. 26, no. 23, pp. 3220-3229, 2016. 


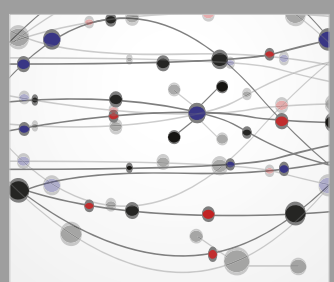

The Scientific World Journal
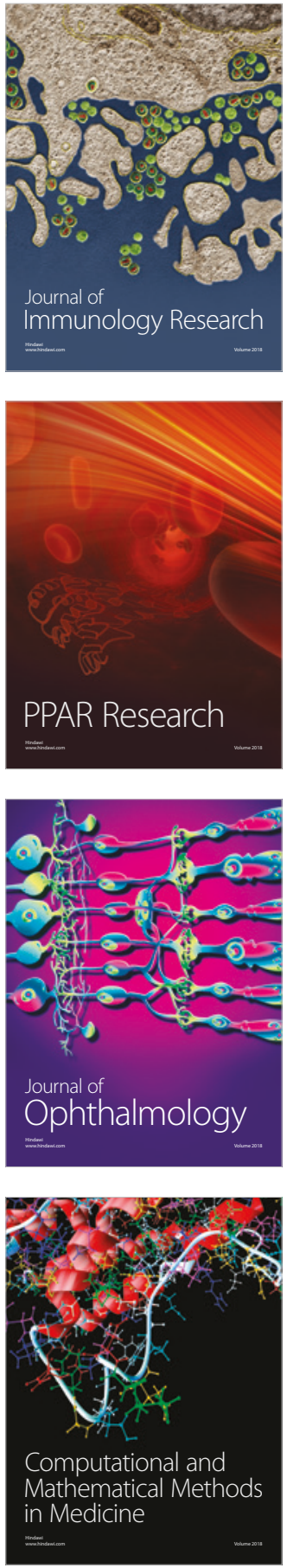

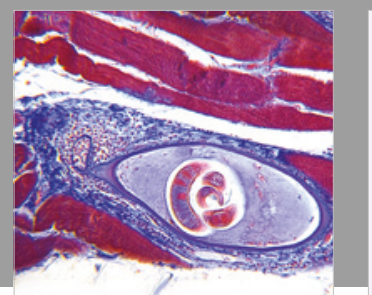

Gastroenterology Research and Practice

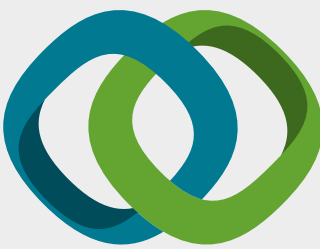

\section{Hindawi}

Submit your manuscripts at

www.hindawi.com
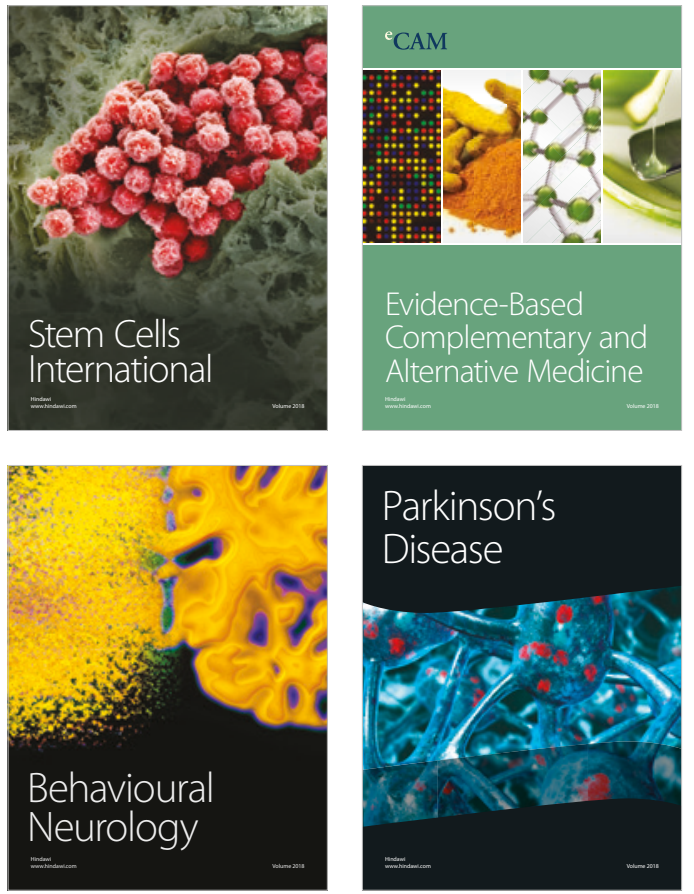

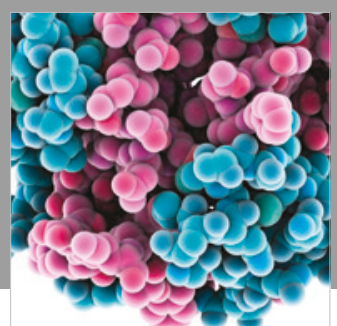

ournal of

Diabetes Research

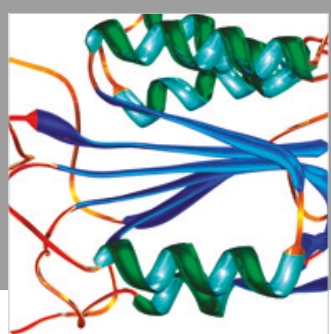

Disease Markers
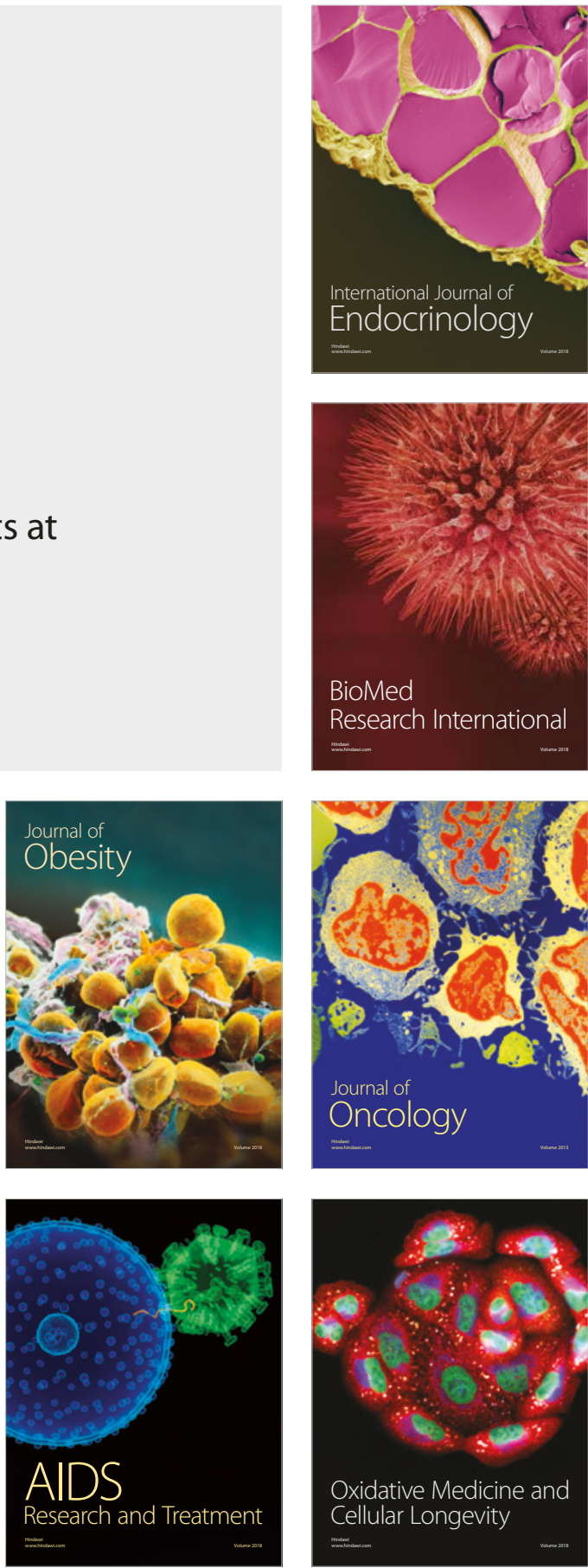